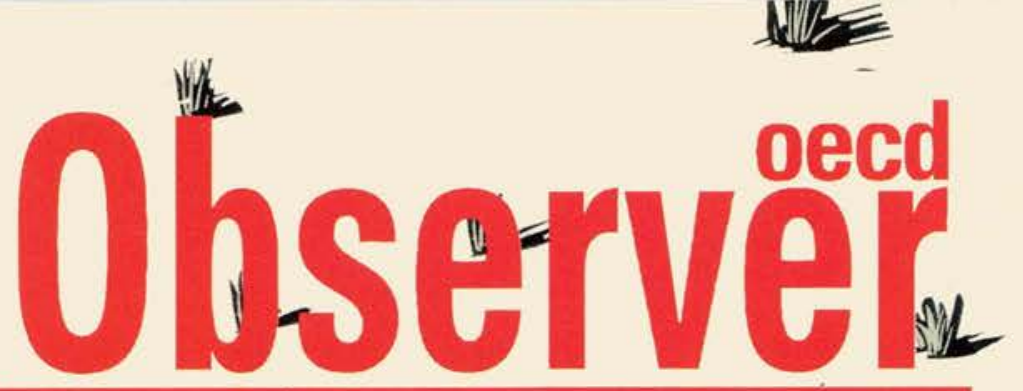

No. 244 - September 2004
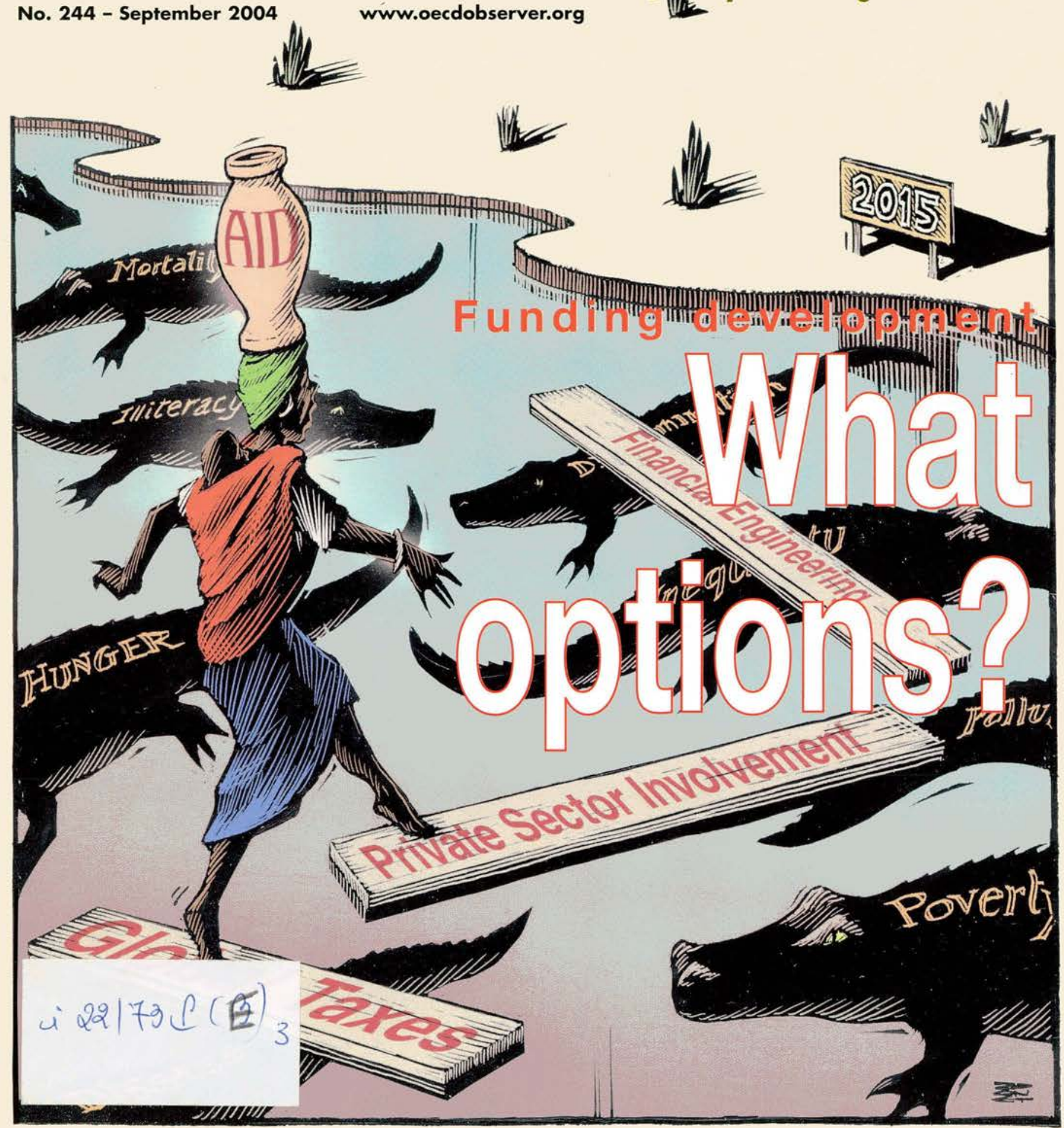


\section{Quality you can rely on}

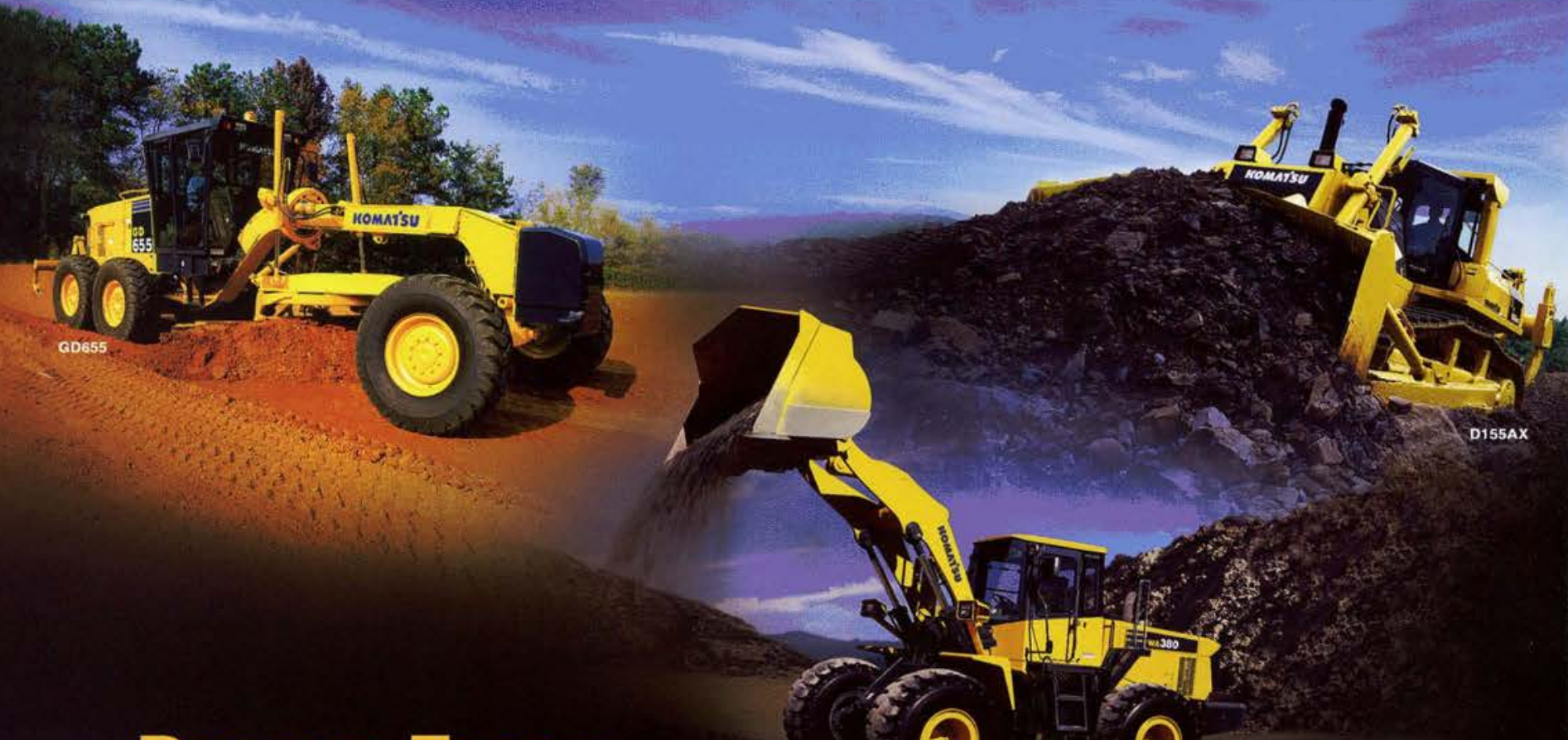

Our Dream Team is built to succeed.

WA380
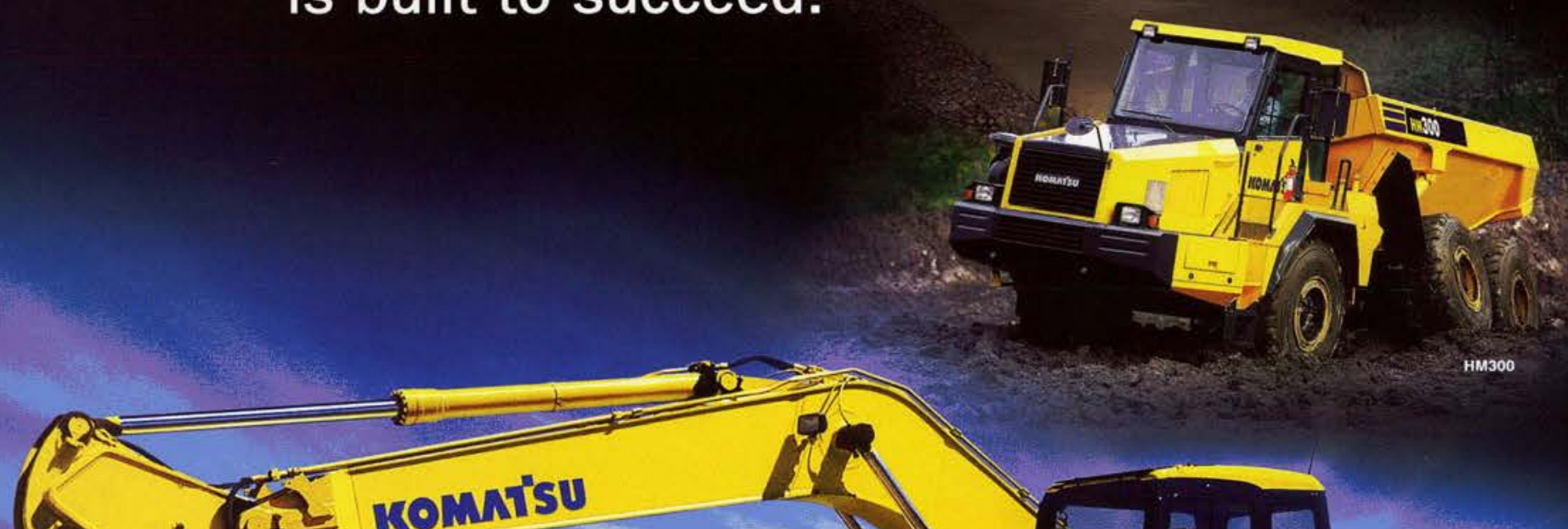

(2.) Komnisu

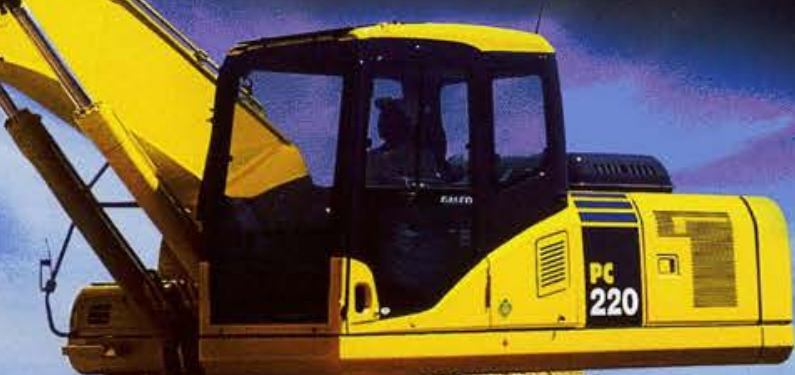

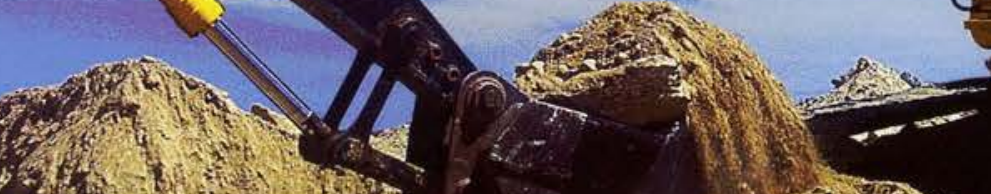

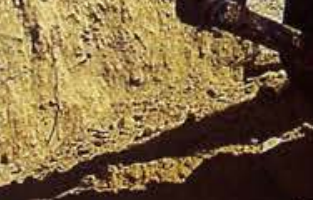

chet Let Win Together

кOMntsu 


\section{Contents}

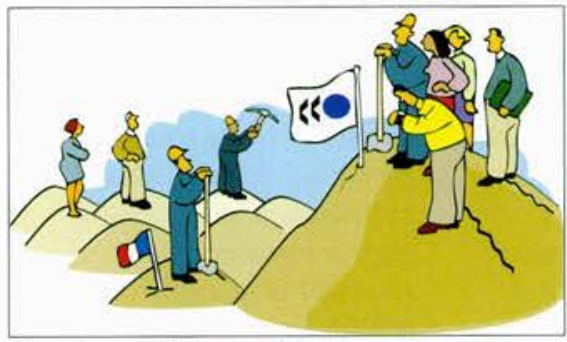

French exception, page 10

\section{LETTERS}

2 Alive, alive, Doha!; Argentina's school angst

\section{EDITORIAL}

3 Global truths

Donald J. Johnston

\section{NEWS BRIEF}

$4 \quad$ Recovery slows?; Trade rises; China leads FDI stakes; Safer pensions; Nuclear choice; No change in jobless rate

\section{ECONOMY}

7 Resilience and risks: Forecast update Jean-Philippe Cotis

9 Better marks for Germany

10 The 35-hour week

Portrait of a French exception

Martine Durand and John Martin

13 Mobile, yet secure

\section{SOCIETY}

14 Was it worth it?

Reflections on a teaching career Kieran Clarke

16 That sense of belonging

$16 \quad$ Frankie.org

No. 244 - SEPTEMBER 2004

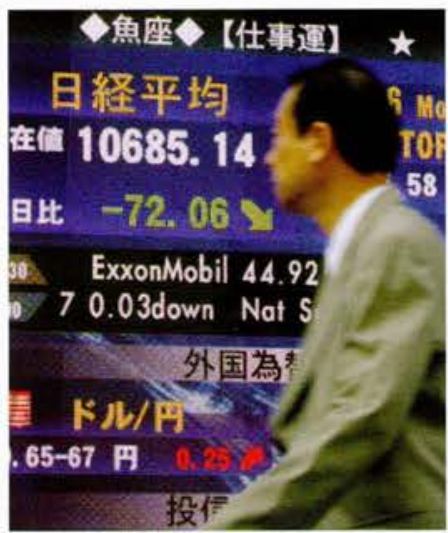

Economic outlook, page 7

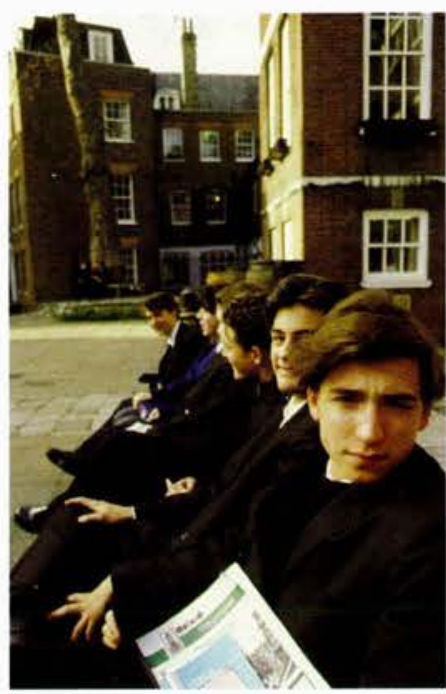

Teaching, page 14

26 New publications list

28 Order form

\section{DATABANK}

29-32 Sum of knowledge; GDP per capita; Health: public or private?; Rising development aid

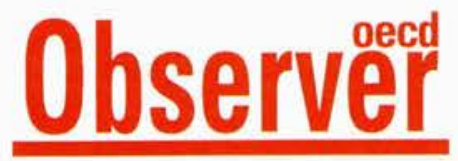

30-31 Economic indicators 


\section{Observề \\ www:oecdobserver org (.) OECD 2004 \\ 2004 subscription rate: \\ E50-US\$56 - E $32-\times 6400$ \\ ISSN 0029-7054 \\ Tel: $+33(0) 145248066$ \\ Fax $+33(0) 145248210$ sales@oecd.org \\ Founded in 1962 \\ The magazine of the Organisation for}

Economic Co-operation and Development

OECD Publications

2 rue Andre-Pascal

75775 Paris cedex 16 . France

observer@oecd org

wwwoecdorg

Published in English and French by $O E C D$ and

Pressgroup Holdings Europe SA

San Vicente, 16-6-1

46002 Valencia, Spain

$\mathrm{Tel}:+34963031000$

Fax: +34963031234

hq@pressgroup,net

EDITOR-IN-CHIEF; Rory Clarke SENIOR EDITOR: Sue Kendall-Bilick STATISTICS EDITOR: Eileen Capponi EDITORIAL. ASSISTANTS:

Alison Benney, Joan Tassy

PHOTO RESEARCH: Silvia Thompson MARKETING: Toby Green

Pressgroup:

PUBLISHER: Angus McGovern DIRECTOR OF PUBLICATIONS. Juan de Dios Leal

Applications for permission to reproduce or translate all or parts of articles from the OECD Observer, should be addressed to:

The Editor,

OECD Observer

2 rue Andre-Pascal,

75775 Paris, cedex 16 , France.

All signed articles and letters express the opinions of the authors and do not necessarily represent the opinion of the OECD.

Reprinted and translated articles should carry the credit line -Reprinted from the OECD Observer", plus date of issue. Signed articles reprinted must bear the author's name. Two voucher copies should be sent to the Editor. All correspondence should be addressed to the Editor. The Organisation cannot be responsible for returning unsolicited manuscripts.

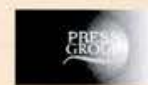

\section{Alive, alive Doha}

You are right to argue that OECD agricultural subsidies (particularly in Europe and the US) always seem to be a stumbling block in the multilateral trade negotiations ("Farming support: the truth behind the numbers", by Stefan Tangermann, see OECD Observer No 243, May 2004). This is the reason why free trade in agriculture is often considered a pipe dream.

Are consumers in these major OECD countries prepared to pay the price? It seems in some cases they are. After all, free trade is not always popular in Europe, where the French in particular seem proud of their rural traditions and will pay a high price to support them. According to a poll by the German Marshall Fund, 16\% of French voters oppose free trade, though as many as $10 \%$ in Germany and the US. Similarly, a high proportion of French voters at 54\% had an "unfavourable" view of globalisation, though Germany was not far behind, at $51 \%$. Both countries were much more unfavourable than the US at $39 \%$ and the UK at $35 \%$.

Thankfully, in a recent round of WTO meetings, the EU announced that it is prepared to negotiate on the issue of agricultural subsidies, and the multilateral talks are back on the rails again. There is reason for cautious optimism.

First, it is good news that the parties are actually negotiating at all, after the breakdown of the WTO talks in Cancún, Mexico last year. The mistake was made of asking for cuts in agricultural subsidies before a procedure was worked out. Fortunately, that problem has now been rectified.
Second, now that the EU has expanded its membership, it has had to devise a two-tiered system of subsidy, which is surely unsustainable. As a result, the average subsidy in the EU budget will probably have to be reduced.

Third, the bilateral and regional trade agreements around the world are in fact a success, because the WTO has had to prove that multilateral negotiations are worth something. Australia has been a strong advocate of bilateral trade agreements - for example, those with Singapore, Thailand and the US - not just for their own sake, but to push for more progress at the multilateral level.

What happens next? The Doha development round has been expanded to twelve months (instead of the original six). This will enable the parties to prepare submissions on market access as well as have time to prepare adjustment packages to deal with the reductions. But most importantly, the multilateral negotiations are still alive and kicking, with some hope for future trade liberalisation on a global scale. Let's hope European and US farmers will see sense and buy in, rather than keeping the rest of the world waiting until the cows come home.

\section{Tim Harcourt}

Chief Economist

Australian Trade Commission Sydney

www.austrade.govau/economists corner

\section{Argentina's school angst}

Your report Education at a Glance 2004 shows how badly Argentine students are lagging behind, not only those in
OECD countries, but also in other "emerging" countries. Finding a job has become hard work for a growing number of Argentine youths, whose low educational attainment casts a shadow over the country's economic prospects. Local businessmen have recently been complaining about shortages of qualified applicants, even for low-skilled workers.

A survey recently conducted by the education ministry highlighted the current asymmetries between supply and demand in Argentina's labour market: over $80 \%$ of vacancy ads published in Buenos Aires newspapers sought upper secondary graduates. But a majority of those on unemployment benefits fall short of this.

Just $41 \%$ of the population at the typical age of graduation have completed high school, compared to the OECD average of $81 \%$. But if the drop-out rate worries educators, employers and government officials alike, the low literacy levels of those who stay at school are generating a lot of handwringing.

The 15-year-olds in Argentina want to do as well as anyone else. Most of them, when interviewed, expect to become high-skilled workers by the age of 30. Their hopes should not be dashed. The country's business people should do more to invest in this "dormant" asset and should encourage the government to do so too. After all, it is Argentina's future we are talking about.

\section{Jorge San Pedro}

Buenos Aires 


\section{Global truths}

Donald J. Johnston, Secretary-General of the OECD

T here are large economic forces at work in the world that carry the potential for immense human progress, but that also can make our economies and societies more vulnerable. Despite the fact that we have known this for at least two decades, since the process of globalisation began to take hold, the international community still fails to secure cooperative action on a scale and nature that will allow all nations to reap the benefits of globalisation.

I am convinced that this period of history will be characterised as the "age of globalisation". Let us make sure historians have a good story to tell, of how world leaders seized the moment to harness untold opportunities to eradicate the poverty, misery and disease in many parts of the developing world; and of how economic growth was firmly established worldwide through the transfer and effective application of capital, technology and know-how, combined with unfettered access to global markets for all. What a wonderful story it could and should be!

Some argue that unequal access to global economic opportunities comes down to a lack of political will. I agree. At the same time, we should be aware that since the end of the Cold War there has been unprecedented political effort and organisation devoted to the cause of international economic co-operation. But while the big picture has developed well, vested interests, especially in the OECD area, have slowed down access to the global economy for the countries and sectors that need it most.

Admittedly, these are often complex issues. Globalisation presents us with new challenges which governments must grasp and make understandable to their sometimes worried or confused citizens. Today, for example, the public in some OECD countries is worried that the outsourcing of business services will undermine employment. The analyses of this phenomenon I have seen demonstrate the benefits of outsourcing to both the OECD countries and to the developing world, and should put such fears to rest provided a clear message gets out.

The efficient operation of global markets and the international economic system is vital to all countries. The health of that system is itself dependent upon effective national policies - both domestic and external - at a time when situations can vary considerably from country to country. A major challenge is to re-establish the facts, with the help of solid data, and dispel misconceptions about globalisation.
Chief among these is the notion that globalisation places draconian limitations on national policies. This statement bears close examination. My own view is that wrong-headed policies that lead businesses and individuals to use their resources or time in wasteful, unproductive ways will bring economic decline and less prosperity, whether or not the national economy is engaged in the global economic system. We have many historical examples of countries that tried autarky and failed.

In contrast, while it is true that the global economy will sanction bad policies, it also provides great economic opportunities, as well as the information needed to harness those opportunities, to countries willing to participate. Globalisation brings benefits, but effective national policies are essential for success. It is certainly not because of globalisation that some economies have experienced a rather disappointing decade. The reason is mostly inertia in the domestic policy reform that must be undertaken to achieve economic and social progress - and to create the confidence the public needs to meet the challenge of globalisation and profit from it.

Related to this is the myth that trade liberalisation damages, rather than furthers, a country's development. The fallacy of protection has been proven time and again, in rich and poor countries alike. As Jagdish Bhagwati once wrote in the OECD Observer, "protectionism in poor countries is quite often the chief culprit in their dismal export and economic performance." Of course, not all developing countries have in place the domestic institutional and economic infrastructure to make a success of rapid market opening. But unless they begin to reduce their tariff barriers and open their services markets in line with their capacities, they will not obtain the positive impulses from competition and lower costs that will help their own industries to grow.

In other words, globalisation should be embraced by all countries, not for the sake of any overarching philosophy, but in their own enlightened self-interest.

Of course, it is more difficult for developing countries to sustain the will to liberalise when they see protectionism entrenched in some of the richest OECD countries. Need I mention the agricultural sector, where political will has been woefully weak, despite the clear benefits of open markets to farming! The lessons about preparing domestic policies and opening markets must be understood and acted on by developed OECD countries. Otherwise, our common aspirations to make globalisation work for all, and so provide future historians - our children - with the positive story they deserve, may not be fulfilled.

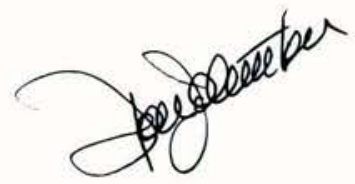




\section{Recovery slows?}

Slowing expansion may lie ahead in the OECD area, according to the latest composite leading indicators (CLIs), which are designed to provide early signals of likely turning points in economic activity. While the economic outlook remains quite bright (see next section), leading indicators collected up to July confirm the weakening performance reported in our last $O E C D$ Observer, with the six-month rate of change deteriorating in all G7 countries, particularly the UK and Italy.

The leading indicator for the OECD area as a whole edged up in July 2004 compared with June, but its six-month rate of change was down for the sixth month in a row, following an upward trend which began in April 2003.

The CLI for the United States increased by 0.1 point in July, but its six-month rate of change fell for the seventh month in a row. And though the euro area's CLI was unchanged in July, its six-month rate of change also fell again. The CLI for

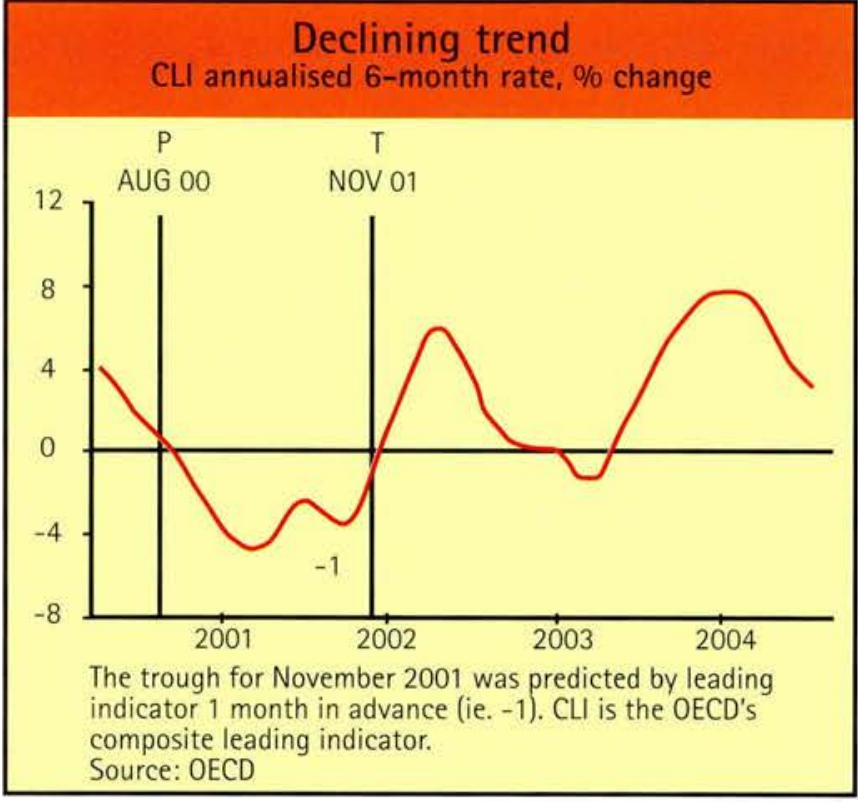

Japan decreased by 0.1 point, with its six-month rate of change down for the sixth consecutive month.

More information on $O E C D$ leading indicators can be found at www.oecd.org/statistics.

\section{Trade rises}

G7 merchandise exports rose by $2 \%$ in volume terms in the first quarter of 2004, while imports into G7 countries increased by $1.3 \%$. This shows a volume increase of $6.9 \%$ for exports and $7.5 \%$ for imports compared with the first quarter of 2003

Compared with the preceding quarter. Germany saw its goods exports up by $6.8 \%$, while imports fell by $0.6 \%$. US export and import volumes expanded by $2.3 \%$ and $2.9 \%$ respectively in the first quarter compared with the previous quarter. While this was slower than previous performances, compared with a year earlier, US merchandise export volumes increased by $9.1 \%$, while imports saw the highest increase in the G7, with $10.4 \%$. Japanese merchandise imports, meanwhile, rose by $8.3 \%$ year on year, while exports jumped by $11.3 \%$.

\section{China leads FDI stakes}

Foreign direct investment (FDI) into OECD countries fell $28 \%$ to US $\$ 384$ billion in 2003, down from US\$535 billion in 2002 and US\$662 billion in 2001. The inflow was about a third of the US\$1.3 trillion recorded in the peak year 2000. The weaker than expected global economic recovery is one reason for the decline, as are concerns about international security, and a preference on the part of many firms to consolidate acquisitions rather than make new ones.

FDI outflows from the $30 \mathrm{OECD}$ countries held up better last year. For 2003 the figures are estimated at US $\$ 576$ billion, up from US\$567 billion in 2002. However, this is still down on $\$ 662$ billion in 2001, while in the peak year 2000 FDI outflows came to $\$ 1.2$ trillion.

The upshot of these trends is that net FDI from OECD countries to the rest of the world showed a substantial increase, from US\$31.7 billion in 2002 to US $\$ 192$ billion for 2003 . This is the biggest net flow to developing countries and emerging markets on record. China, which in 2003 attracted U\$53 billion from OECD countries and elsewhere, replaced the US as the biggest recipient of foreign direct investment. The size of domestic markets, rather than lower wages and production costs, in emerging economies appears now to be the main attraction for OECD companies. 


\section{Safer pensions}

If today's employees are to enjoy adequate retirement pensions in the future, more efficient regulation and management of company pension schemes are needed. At present, many company pension funds are faced with numerous risks, for example, from volatile stock markets or poor management. To reduce the risk of such situations, and in cooperation with the International Network of Pension Regulators and Supervisors, the OECD has published a new Recommendation inviting governments to encourage implementation of the following six Core Principles of Occupational Pension Regulation. They are: conditions for effective regulation and supervision; establishment of pension plans, pension funds, and pension fund managing companies; pension plan liabilities, funding rules, winding up, and insurance; asset management; rights of members and beneficiaries and adequacy of benefits, and supervision

It also recommends several other steps, for instance, that companies aim to ensure that the assets of their pension funds fully cover potential liabilities, including providing information about pension funding in their financial reporting so that investors are made aware of any shortfalls. In addition, companies should create separate legal entities for their pension funds to help ensure, for example, that if a company goes bankrupt, the pension funds of its employees remain safe. Further, the investment of a company pension fund's portfolio in the shares of that same company or its parent company should be prohibited, or at the very least, strictly limited. A full list of the recommendations can be found at www.oecd.org/dataoecd/14/46/33619 987.pdf or on www.oecd.org/daf.

\section{Nuclear choice}

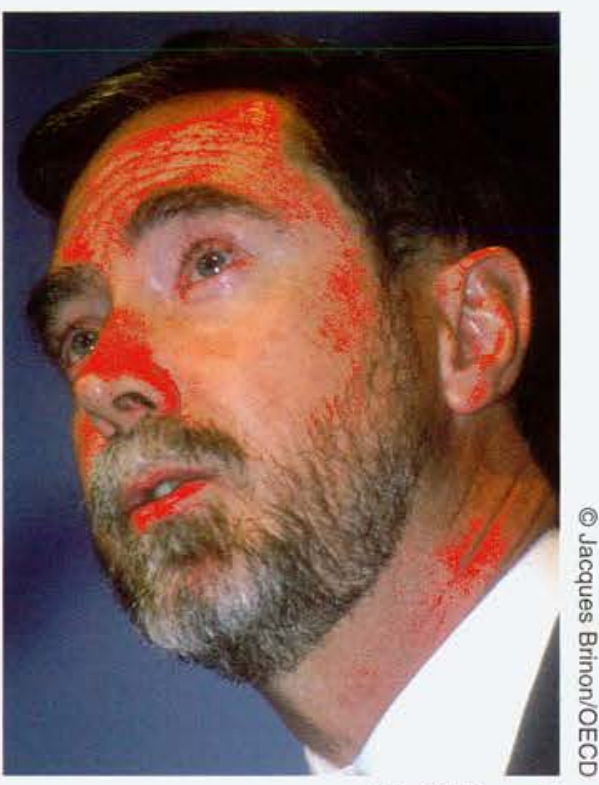

Mr Echávarri

Could nuclear energy play a role in the current environment of high oil prices? During a session of the 19th World Energy Congress in Australia, Luis Echávarri, Director-General of the OECD Nuclear Energy Agency (NEA), stated that the debate on nuclear energy "could not be timelier.

The coming years will be crucial in determining what contribution nuclear energy will make to the world energy supply, he said: "As a large-scale, nearly carbon-free energy source, it is one of the cheapest ways to reduce GHG emissions." Mr. Echávarri stated that the energy's availability and affordability, as well as its low carbon emissions, were driving many governments to reconsider nuclear power, which is already making an important contribution to the diversification of energy resources. Nuclear power currently provides $16 \%$ of the world electricity supply, reducing global $\mathrm{CO}_{2}$ emissions by nearly $10 \%$.

The NEA consists of 28 OECD member countries. See www.nea.fr. = 


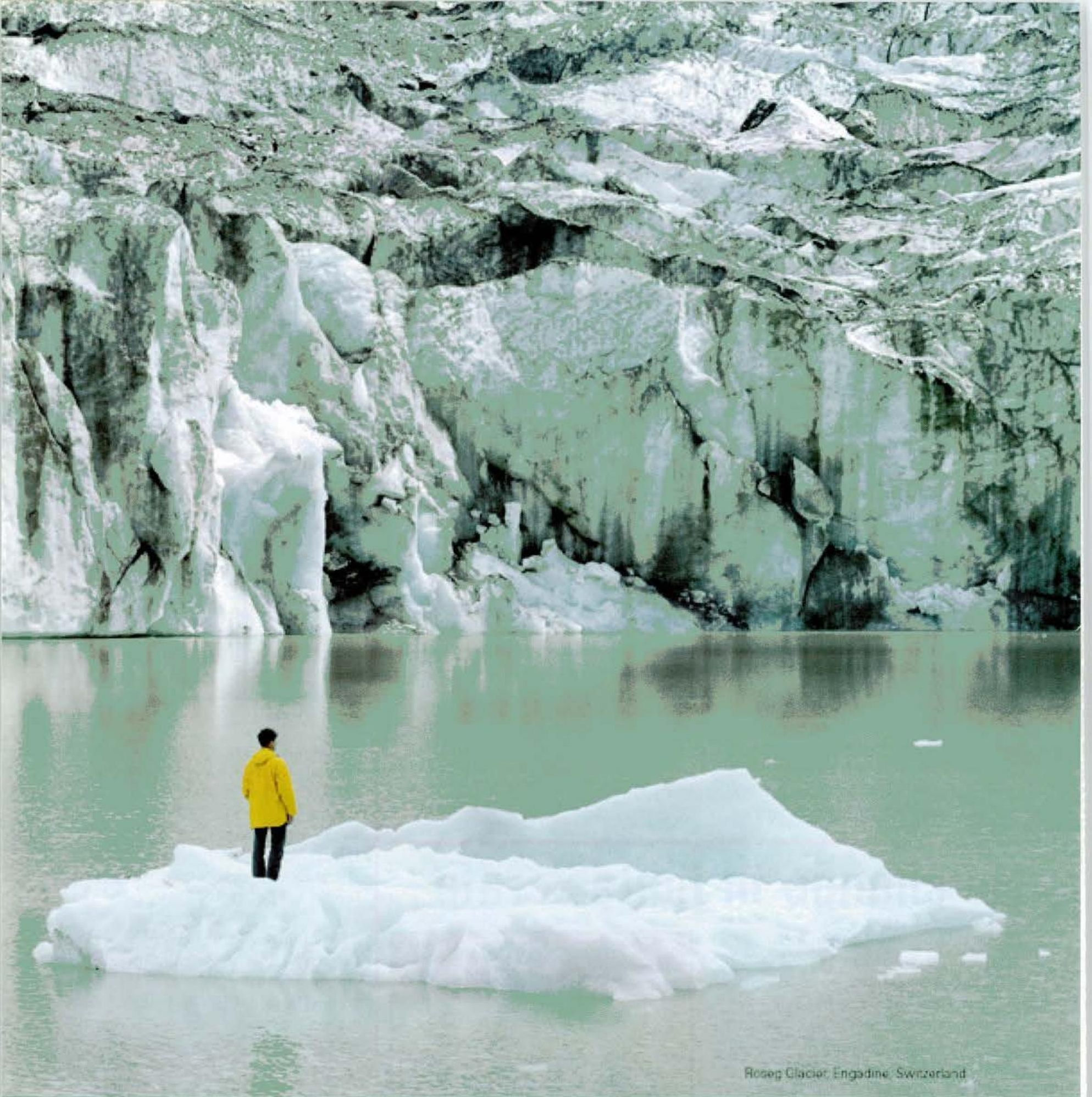

Thomas Streiff, Sustainability Expert, Swiss Re

Thomas Streiff and his team identify ervisonmental and man-made risks and develop sustainable strategies to cope with them. For example, Swiss Re was arnong the first to recognise the potential impoct of climate change on the financial services industry and to study effective ways of managing associated risks. Offering a combination of expertise and financial strength, Swiss Rie is ideally positioned to provide your company with taillared solutions to mitigate yout exposure and protect your bolance sheet - ensuring. in a climate of uncertainty, that you feet secure. www.swissre.com 


\section{Resilience and risks}

\section{Economic outlook update}

Jean-Philippe Cotis, OECD Chief EConomist

The momentum of the recovery projected in our Economic Outlook last spring has been only marginally dented so far by higher oil prices. By and large, the recovery continues to unfold as forecast at that time, with real GDP set to expand by around $3.5 \%$ in 2004 in the six largest OECD economies as a group.

$\square^{c}$

conomic activity has become somewhat weaker than we had projected in the United States and somewhat stronger in the euro area and Japan. While rising oil prices have exerted upward pressure on headline inflation, core inflation in OECD countries has been stable. Until now, there have been no visible "knock-on" effects in the form of higher wage claims, not least because inflation expectations remain well anchored, in a context where central bank commitments to price stability are rightly seen as robust and credible. As a result, the negative impact of oil market turbulence has been limited to date.

With policy stimulus beginning to fade, US expansion increasingly hinges on employment creation and business investment. Household confidence has been affected by the slow pace of job creation recorded so far, but remains around its long-run historical average, and this bodes well for resilience in consumption. Firms are much more

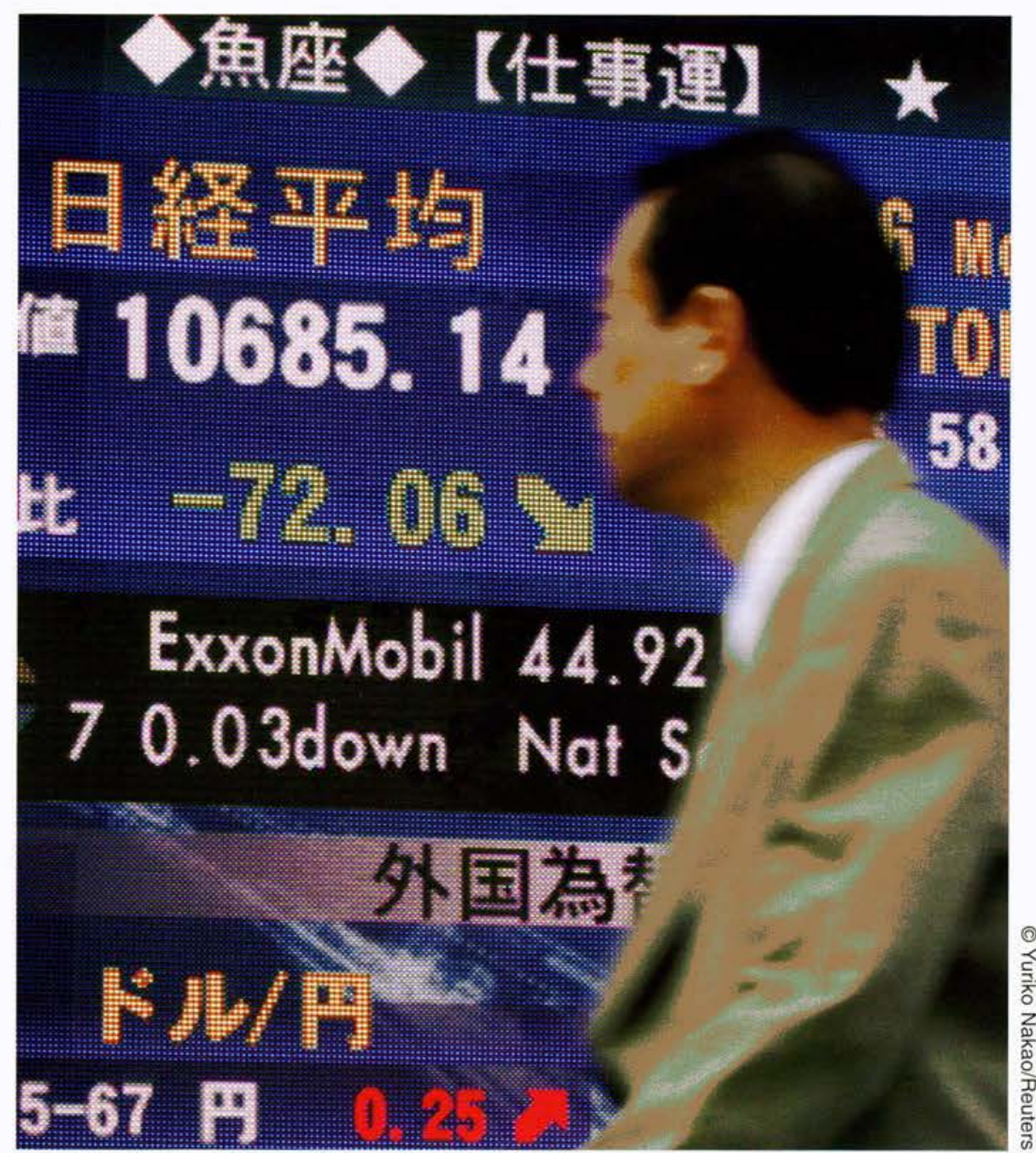

upbeat than consumers. They have taken advantage of the prolonged spell of historically low interest rates to strengthen their balance sheets and enjoy ample profits. This should allow for robust business spending and greater hiring.

In the euro area as well, businesses are in a somewhat better mood than households. Real GDP, which was surprisingly strong earlier in 2004, is expanding at around its potential rate, albeit still over-reliant on external demand. Moreover, compared with the US, economic activity in Europe remains slack. Meanwhile, stark differences persist within the euro area, with domestic demand buoyant in France, but still lackluster in Germany. Italy lags 


\section{Trade is decelerating in Asia}

Trade growth in Dynamic Asia*, 3 months on previous 3 months, \% change

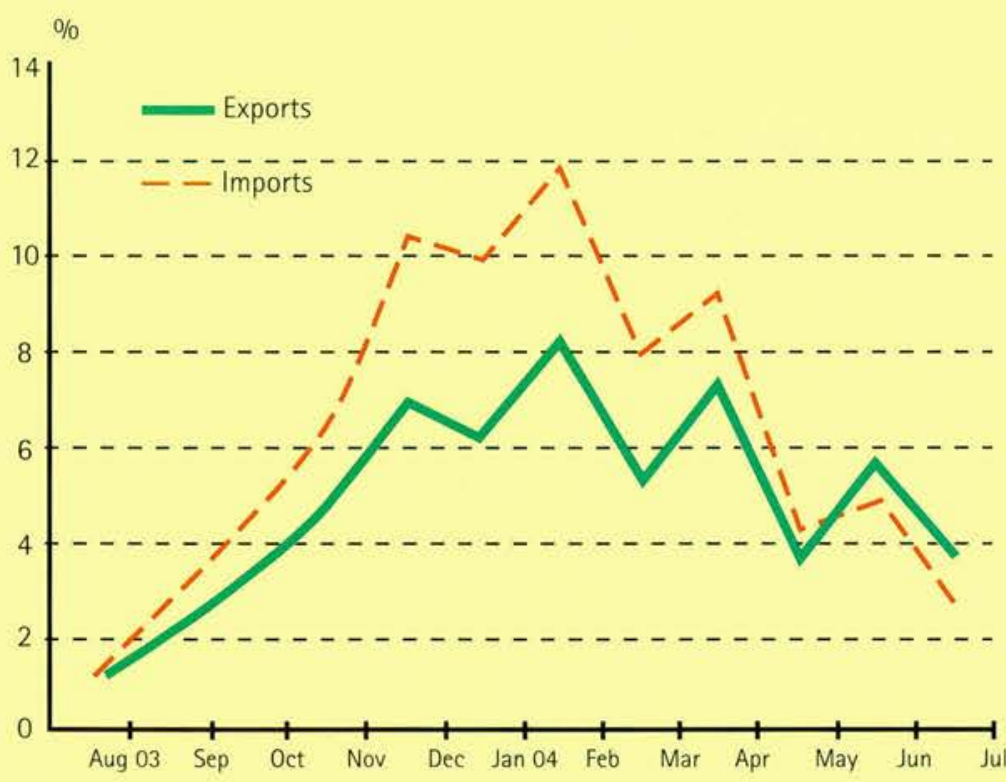

*Includes Chinese Taipei, Hong Kong, China, Indonesia, Malaysia, the Philippines, Singapore and Thailand. Source: OECD.

behind, due to both competitiveness problems and weak domestic demand. The resilience shown so far by OECD economies in an environment of geopolitical uncertainties and turbulence in oil and commodity markets suggests that, looking further ahead, growth should remain solid. Nonetheless, further increases in oil prices or a sharper, more prolonged slowdown in China than currently forecast could pose a risk to this outlook.

Growth in Japan and China has slowed from the very rapid pace of early 2004 , but in both cases sustained expansion remains the most likely scenario. In Japan, domestic demand growth continues to rely heavily on business fixed investment, against the backdrop of strong profits. Firms are hiring, but overwhelmingly in the form of nonpermanent contracts and in a context where wages are not yet recovering. Household confidence is improving, but needs to strengthen further. Japan is nonetheless finally in a position to lift itself out of its deflation trap, provided macroeconomic policy stays the course and structural reforms, including in the financial sector, are pursued.

Against the background of a continuing recovery, several central banks, including the US Federal Reserve, have started to rein in the exceptionally vigorous stimulus they had injected to foster the recovery. With the global recovery spreading more widely, monetary tightening should be progressively extended to other parts of the OECD. However, the pace of tightening will depend on the speed with which spare capacity is shrinking and the extent to which core inflation remains under control. Under the present circumstances of weak domestic demand in the euro area and mild deflation in Japan, the current "wait and see" stance of their monetary policies seems warranted.

Fiscal consolidation should begin in earnest though, not just to avoid procyclical impulses as business slack is worked off, but also to deal with the mounting pressures faced by all OECD countries as their populations age, in combination with further reforms of pension and health systems. At this point, governments have much to do. Deeds speak louder than good intentions, and permanent adjustment measures are now called for to restore overall sustainability to public finances.

This article is based on a press briefing given by $\mathrm{Mr}$ Cotis at the OECD in Paris on 21 September, 2004.

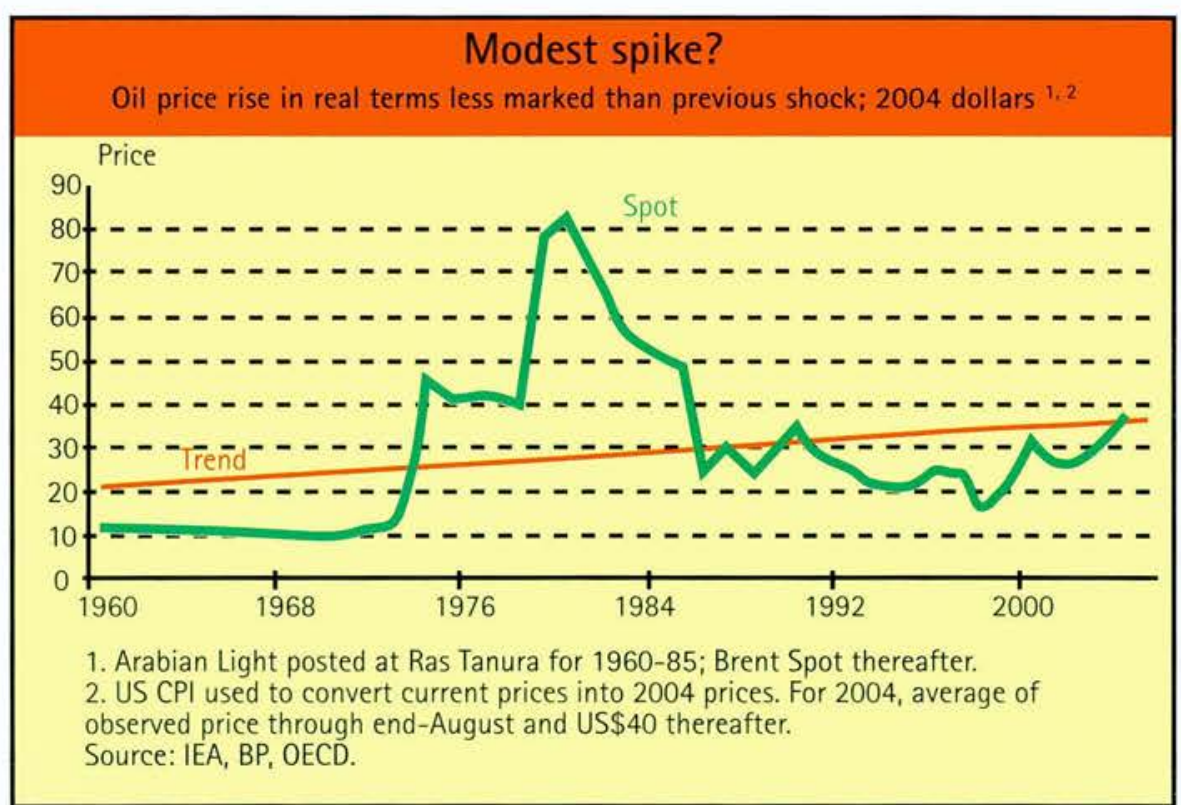




\section{Better marks}

for Germany

$\mathrm{T}$ he German economy is at last emerging from a three-year period of near stagnation.

Domestic demand had been shrinking over the last couple of years, as a poor labour market performance weighed down on consumer and business confidence. But, as the latest $O E C D$ Economic Survey of Germany points out, a strong and competitive export industry is helping the OECD's third largest economy recover its strength as world trade growth expands more rapidly. Private consumption should firm up as disposable incomes rise on the back of phased income tax cuts Personal outlays for some routine healthcare expenses will rise as part of current cost-cutting reforms, and some indirect taxes are being raised as Germany reins in its fiscal deficit.

Overall, the latest Economic Survey of Germany expects rising demand at home and abroad to lift profits and feed into stronger investment in machinery and equipment. Construction, though, should remain in the doldrums, and the survey sees no rapid turn-around in the labour market.

For more than ten years real GDP growth has lagged that of some other $\mathrm{OECD}$ countries. Sure enough, productivity has grown in what continues to be a highly innovative economy, but it has not risen fast enough to compensate for the weaker contribution to growth from employment. In fact, there has been a rise in unemployment, caused mainly by structural blockages in the economy, with high overall wage costs and tight legislation weighing down on labour. Even when business is up, these obstacles make employers think twice before hiring new workers.

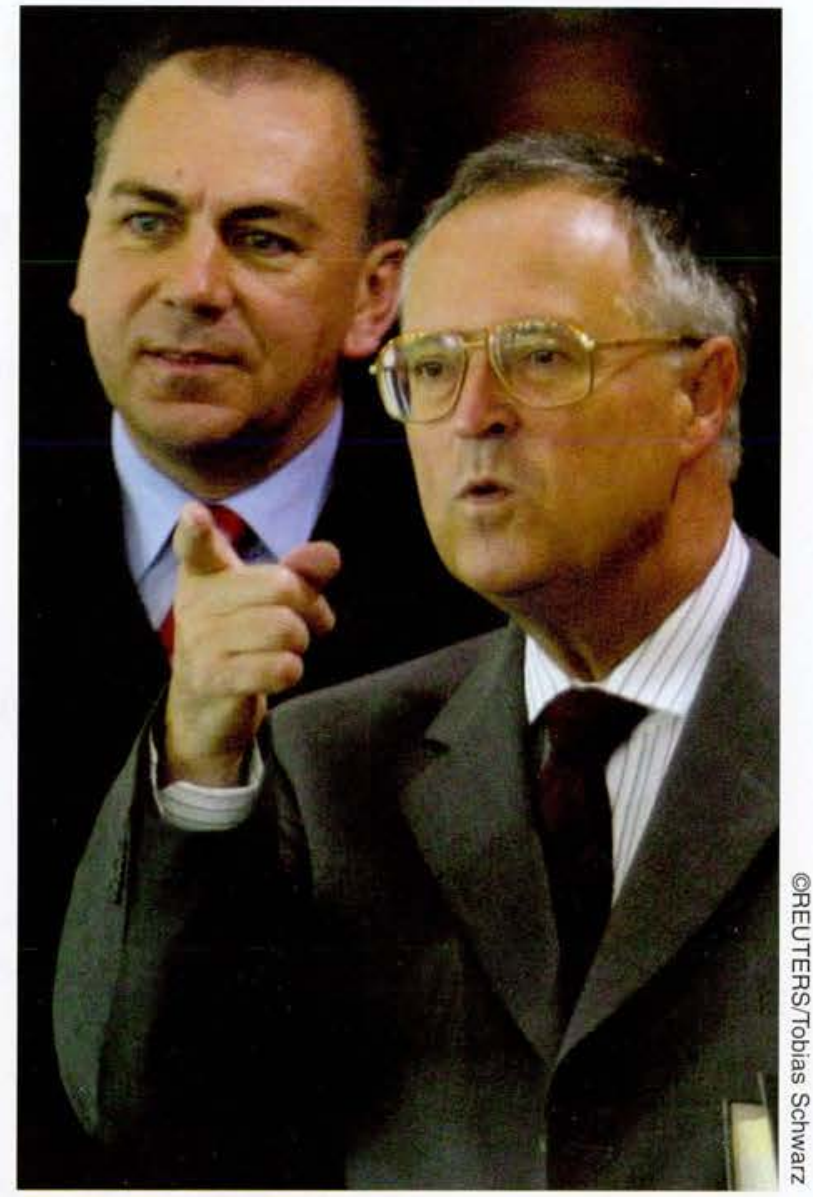

Challenges ahead: German Finance Minister Hans Eichel (right) and Bundesbank President Axel Weber
The government is taking action. Reforms to reduce barriers for higher employment and other structural reforms under Agenda 2010, affecting pensions and competition for instance, are to be welcomed. However, the survey urges these reforms to be broadened further to reduce government debt, remove fiscal distortions and make the labour market more responsive to supply and demand.

While German innovation remains among the world's best, it has slipped back a little in recent years. Restoring it demands measures to reignite German entrepreneurship, and the report points to "considerable scope" to foster the creation of new enterprises and deepen competition.
The 150-page OECD Economic Survey on Germany comes complete with basic statistics, graphs and tables. As well as analysis on the German business cycle, chapters cover issues arising from unification, public sector reform, fiscal consolidation, employment, competition and innovation.

\section{OECD Economic Surveys are} published for all member countries as well as selected non-members. They are a reference for economists, business analysts and policymakers the world over. Other recent surveys have been published on the Euro area, the Netherlands and non-member Russia. For a detailed list and order details, please see page 26-27 or visit www.oecd.org/eco. = 


\section{The 35-hour week}

\section{Portrait of a French exception}

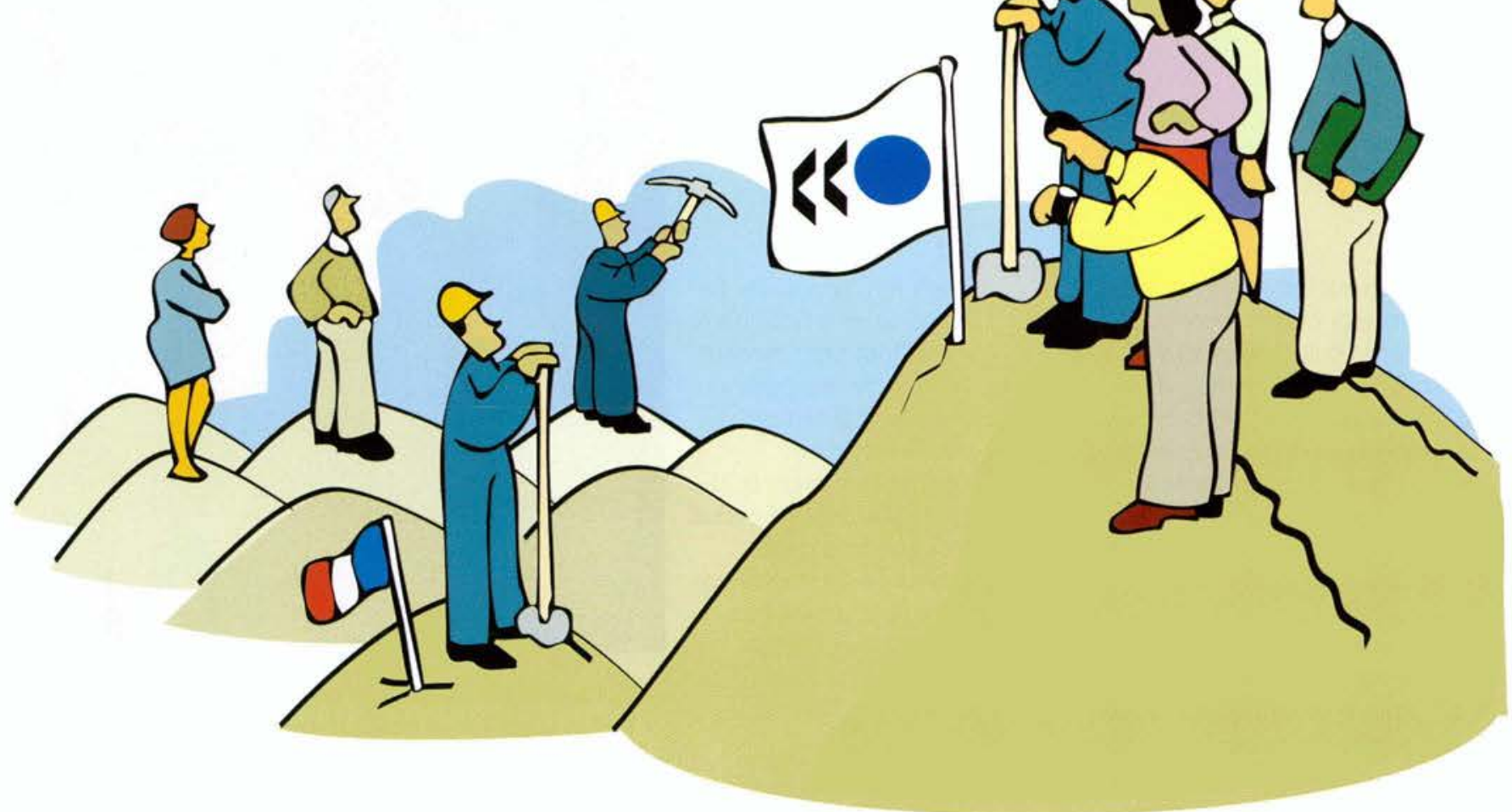

The notion that cutting working time could be an integral part of the fight against high unemployment has been a very controversial one, particularly in Europe. Yet, such was the main policy initiative of the French government in the employment field over the second half of the 1990s.

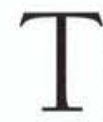
he enactment into law of the 35-hour week in 2000 was the outcome of a long process that gave rise to vigorous debates, notably between employer organisations, trade unions and the government. No other OECD country has opted to follow France down the road of legislating shorter working time as a weapon to increase employment and cut unemployment.

At the same time, the debate within France on the 35-hour week is not over. The legislation implementing the 35-hour week has been eased recently in several important respects, and a recent report by a commission of the French parliament has stirred up more controversy, with proposals to introduce still more flexibility in the law.

A reminder of the context and objectives is useful here. The genesis of the 35-hour week can be traced back to 1996, with a bill (the socalled loi de Robien) that offered large financial incentives for firms to create new jobs or preserve existing ones through work-sharing. The process was launched in a context of high and persistent joblessness, with the unemployment rate touching $12 \%$. The main aim was therefore to increase employment, but improving 
working conditions and facilitating the reconciliation between work and family life were also highlighted as objectives.

The trigger for much controversy and debate came afterwards with the bill passed in 1998, the so-called first loi Aubry. It reduced the legal work week from 39 to 35 hours as from 1 January 2000 , while leaving much of the details of implementation to be decided by collective bargaining between firms and unions. A second Aubry bill was passed in 2000. Most of the provisions of the new law were based on the negotiations held over the previous two years, introducing new guarantees for both companies and employees. In particular, it introduced greater options for working-time flexibility, tailored to the needs of firms.

Under the new law, in any given year, the average work week must be 35 hours, but firms can set high and low activity periods over the year, so long

\section{Today, annual hours worked per employee in France are $8 \%$ below the EU average, and among the lowest in the OECD area.}

as this average is respected.

Consequently, firms can adjust the work week to fluctuations in activity. The law introduced rebates on employers' social security contributions, so long as there was a collective agreement on working time. Finally, the new law created a guarantee for employees earning the legal minimum wage, which was designed to prevent a fall in their real incomes as a result of shorter working hours.

Have these reforms led to a further fall in working hours? Already, for more than 30 years, most OECD countries had experienced a reduction in working hours, reflecting both an increase in productivity and the rise in

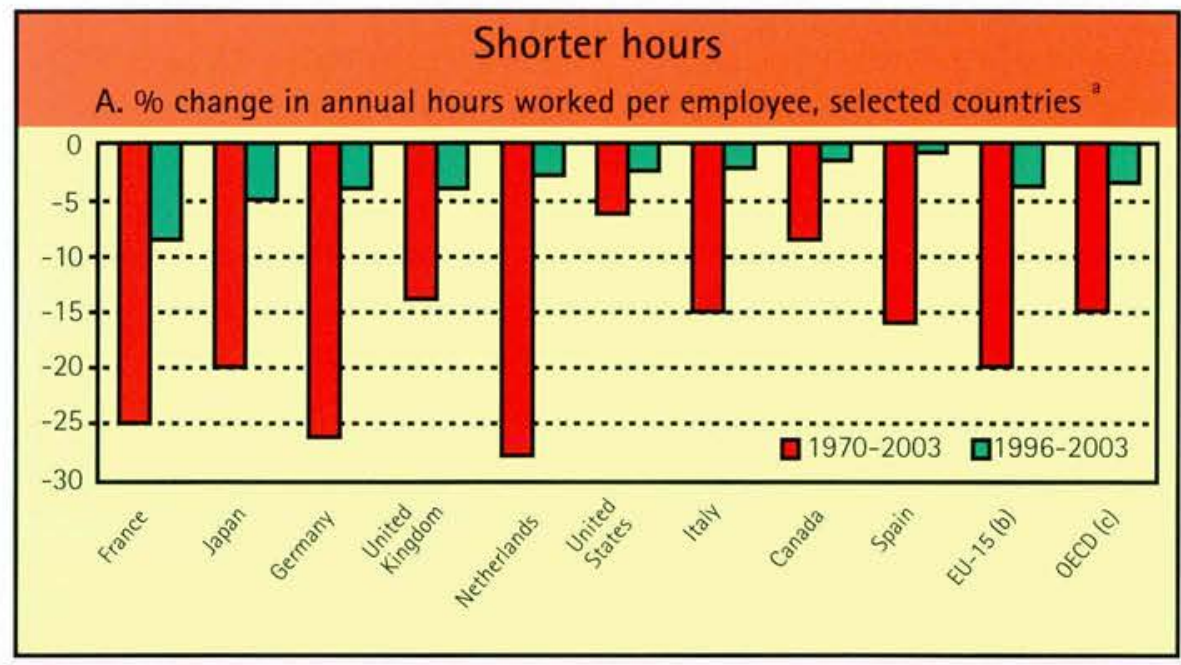

B. Number of annual hours worked per employee

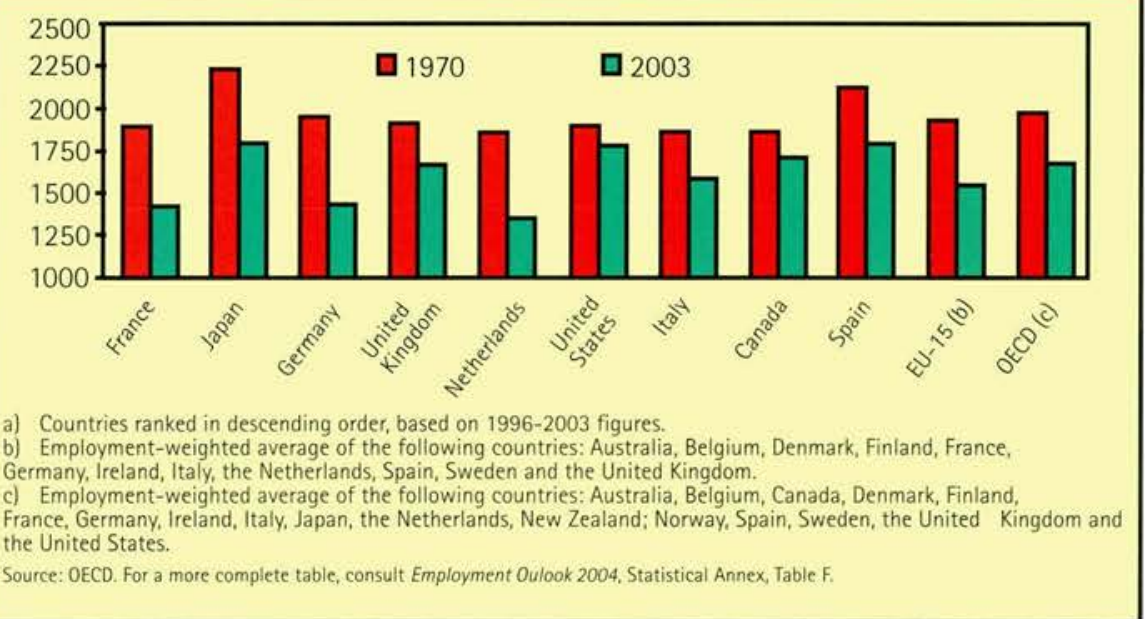

the number of part-time jobs (many of which are linked to the higher number of women in the labour market). But France already stood out with a particularly sharp fall.

Today, annual hours worked per employee in France are $8 \%$ below the EU average, and among the lowest in the OECD area (see graphs). This gap widens to $17 \%$ when comparing France with Canada, and to $20 \%$ if compared with the US, Japan,

Australia or New Zealand. A far cry from the 1970s when annual hours worked per employee were almost identical across the OECD area. France also recorded one of the steepest declines in annual hours worked over the past decade, mainly reflecting the impact of the 35 -hour week.

If the recent trend in hours worked in France is somewhat exceptional, the measure which triggered it is equally so. In fact, while some other OECD countries have taken steps to cutting working time on an economy-wide basis, such as the Netherlands in the early 1980s and Germany in the second half of the 1980 s, these initiatives have rarely been introduced officially, through legislation. They were, for the most part, the result of negotiations, on a case-by-case basis, between the social partners, without direct government intervention. 
Another aspect of the French exception lies in the fact that, for the majority of workers who had switched to a 35-hour week, their monthly salary was maintained. In order to offset the impact of this income guarantee on costs and competitiveness, the government cut payroll taxes for French firms, while the unions agreed to a partial wage freeze for one to three years. Moreover, as workers would increase their work effort and firms reorganise their production methods, there was an expectation that hourly productivity growth would increase. point to a best-case net increase of some $300,000-400,000$ jobs in 2003. The trouble is, the subsidies granted to companies by the 35 -hour bill have added to the public deficit, and this in turn could drive up the public debt. The loser in the long run could be employment.

Another problem is that while hourly productivity rose, this was not enough to compensate for the fall in the number of hours worked per employee. Each hour worked may have been used more efficiently, but the shorter working week caused

\section{One clear benefit of the 35-hour week legislation is that it provided firms with much-needed flexibility in working-time arrangements.}

Has the 35-hour work week fulfilled its objectives? It is still too soon to pass a definitive judgement. Employment has risen in France since 1997, but some of this rise was due to favourable economic conditions, rather than the 35-hour reform. In any case, other EU countries recorded larger rises in employment over the same period.

One clear short-term benefit of the legislation is that it provided firms with much-needed flexibility in working-time arrangements. Rigid working-time schedules were liberalised and this may have led to some gains in productivity. In fact, productivity gains per hour worked were relatively high in France in 1996-2002, compared with many other OECD countries.

These hourly productivity gains, combined with cuts in employer payroll taxes and some wage moderation, probably helped keep the lid on unit labour costs for a while. This may have favoured job creation. How much is hard to say, but calculations by various French research institutes and the OECD productivity per worker to fall. This may have reduced the long-term productive potential of the French economy.

There are pluses, though. On the workers' side, almost two out of three employees report that the transition to the 35-hour week has improved their living conditions. And among workers with young children, $60 \%$ state that it facilitated the reconciliation between work and family life. However, since the 35-hour week brought about considerable work reorganisation, some employees, mainly unskilled and women, have been left not just with less overtime pay, but with more unpredictable working hours as well. Among women for instance, only $40 \%$ of blue-collar workers saw their living conditions improve with the 35-hour week compared with over $70 \%$ of their white-collar counterparts.

Five to six years on, some preliminary conclusions can be drawn about this reform. The 35-hour week has probably created some jobs, but it has been costly and its long-term impact on job creation remains uncertain. It worsened public deficits and it is not clear if it was the most cost-effective use of public funds for job creation. In particular, a more targeted approach to improving access to employment for disadvantaged and low-paid people would have been preferable. In this regard, the main thrust of employment policy during the first half of the 1990s to reduce overall labour costs at the bottom of the wage ladder, was probably more appropriate.

Moreover, in a context of population ageing, where it becomes crucial for governments to mobilise more of the potential labour force, cutting working time is certainly not the best policy option.

The government has recently eased part of the legislation, making the use of overtime easier and less costly for firms and exempting many small and medium-sized firms. The debate continues as to whether further easing would not be desirable, and if so, how to do it as painlessly as possible.

\section{References}

- OECD (2004), "Clocking in (and out): Several Facets of Working Time", OECD Employment Outlook 2004, Paris.

- OECD (2001), "Annex IV, The reduction in working time: a post-mortem on the 1999 Interlink simulations", Economic Survey of France, OECD, Paris.

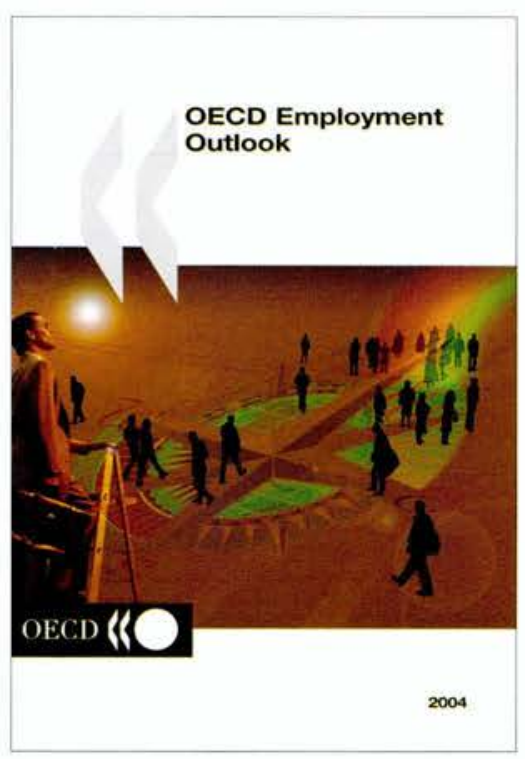




\section{Mobile,}

yet

secure

A nyone who wonders whether a flexible labour market can exist alongside a robust social security system should look no further than Denmark. There, employment protection legislation is less rigid than in some of its neighbours, but unemployment benefits are higher than in more deregulated Anglo-Saxon countries. On the other hand, seriously hunting for work is a precondition of receiving those benefits. The upshot is that while many workers may be affected by unemployment every year, most of them return to jobs quickly. Those who do not, must take up demanding job activation programmes to help them get back on track.

Flexicurity, a term coined by the Dutch for a (slightly different) initiative in the 1990s, is how the Danes also describe their "third way" between extreme deregulation and over-protection. It appears to deliver results. In Denmark unemployment averaged just $5.6 \%$ in 2003 , half its rate of a decade earlier.

How does flexicurity work? Most insured unemployed people in Denmark receive benefits from their first day out of work, which come to some $90 \%$ of their previous income, for a maximum of four years. For low-income groups, this income and other income-related benefits go some way to replacing the kind of net earnings a job, which itself may be highly taxed, would pay. This net income replacement rate varies from $63 \%$ to $78 \%$ for an average worker,

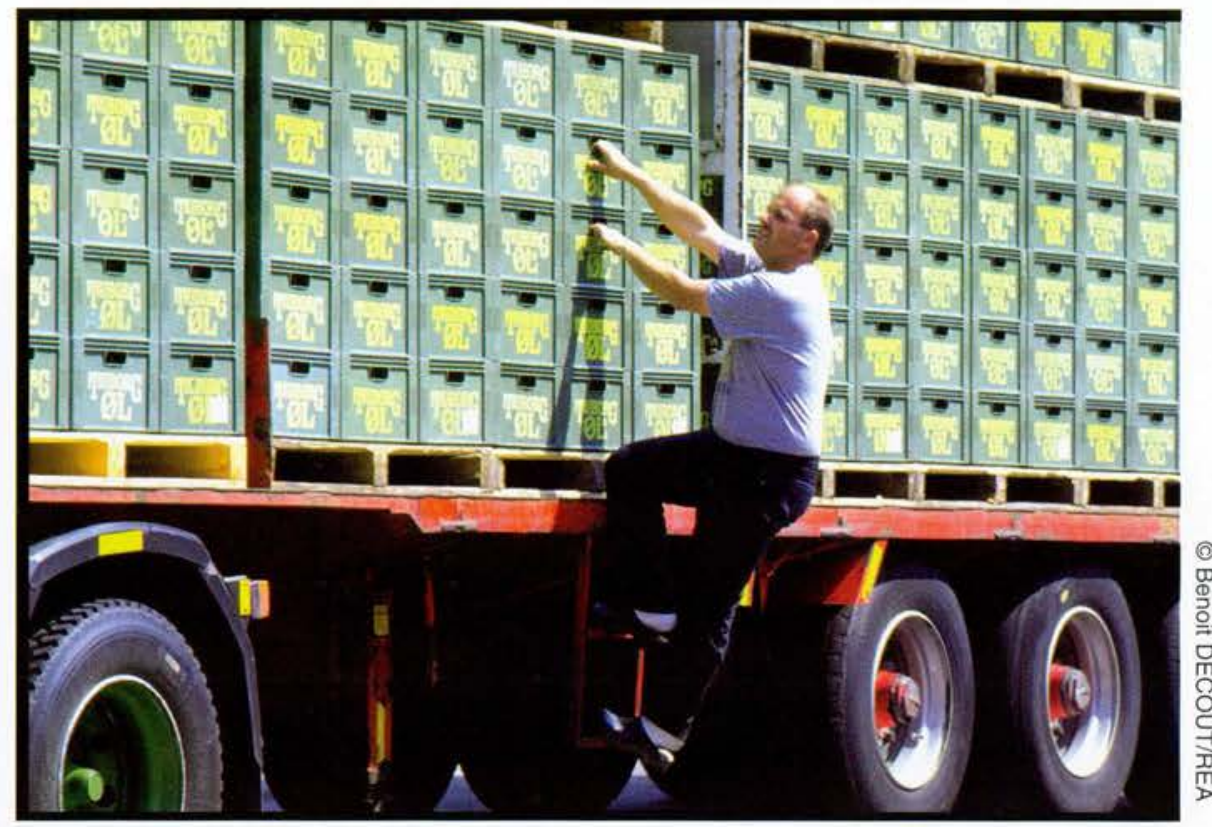

depending on the family situation, and climbs as high as $89 \%$ for a single individual from a low income group, and to $96 \%$ for a lone parent with two children. Clearly, based on income alone, the unemployed would have little incentive to find a job fast. That is where the activation rules come in.

In Denmark, recipients of unemployment benefits are required to seek a job. And a law passed in 1994 made it obligatory for adults that are more than 12 months out of work to participate in so-called activation programmes. Under 25 s have only six months to find work before activation becomes mandatory. The result is that Denmark's long-term unemployment rate, at about a fifth of total unemployment in 2003, was lower than in the UK $(23 \%)$ or indeed the Netherlands (29\%).

A Danish activation period lasts for up to three years and may include private or public job training, job search courses, targeted education, and the like. If, after this period, the unemployed person still fails to find a proper job, they will lose their benefit entitlement, but will still be eligible for means-tested social assistance, whose net income replacement rate is far lower.
Although flexicurity produces results, such programmes can be costly, both in administration and transfers.

According to a report by Per Kongshøj Madsen, government spending on labour market programmes, including benefits and active labour programmes, comes to $5 \%$ of GDP.

Flexicurity aims not just to cut unemployment, but to boost the size of the active workforce too. Under reforms in 2003, dubbed "more people into employment", benefits are still available for four years, but activation programmes can kick in from the very first day of unemployment. The aim is to provide faster, more direct paths into work by using focused individual action plans and leaning more heavily on public employment services. By getting people into work, flexicurity can pay its way, but whether it can bear fruit in a less favourable economic climate than that of recent years remains to be seen.

\section{References}

- Madsen, Per Kongshøj (2002), "The Danish Model of Flexicurity: A Paradise with some Snakes", European Foundation for the Improvement of Living and Working Conditions, Brussels.

- OECD (2004), Employment Outlook 2004, Paris. 


\title{
Was it worth it?
}

\section{Reflections on a teaching career}

\author{
Kieran Clarke*
}

\section{Graduate teaching courses are becoming more} popular again in many countries, though ageing continues to affect the profession, and making the career more attractive for longer remains a challenge. For insight, we asked a retired teacher to explain why, despite the challenges, he stayed in the job.

$\mathrm{T}$ here were three routes into teaching when I arrived in London at the end of the 1960 s with my bachelor's degree and an abiding love of English literature: drift, career decision, or two years on approval. I opted for the third and was prepared to give it a good go as long as people called me a school teacher and not a schoolmaster, which I found stuffy and inaccurate

Political efforts in the mid-1970s to give teachers a good basic salary provided some incentive to stay in the job, but what nailed it for me was the fact that after two years I found myself in a secondary school with a thriving sixth form (final year) and regular successes at Oxford and Cambridge entry. It was the kind of school in which a teacher might just decide to spend an entire career. But the school met with difficult times. It became a multicultural school with the majority of pupils coming from immigrant families. About a third of pupils are now considered as having Special Educational Needs and the number of pupils on Free School Meals, a programme designed for very poor families, is over twice the national average.

Over the past 30 years, I have watched teachers having to cope with a litany of changes that shaped the history of today's education: the advent of comprehensive schools, a national curriculum, the Baker reforms that destroyed the dream of a true comprehensive system in which every child would have an equal educational opportunity, regardless of background, class or ability. Then there were the Standard

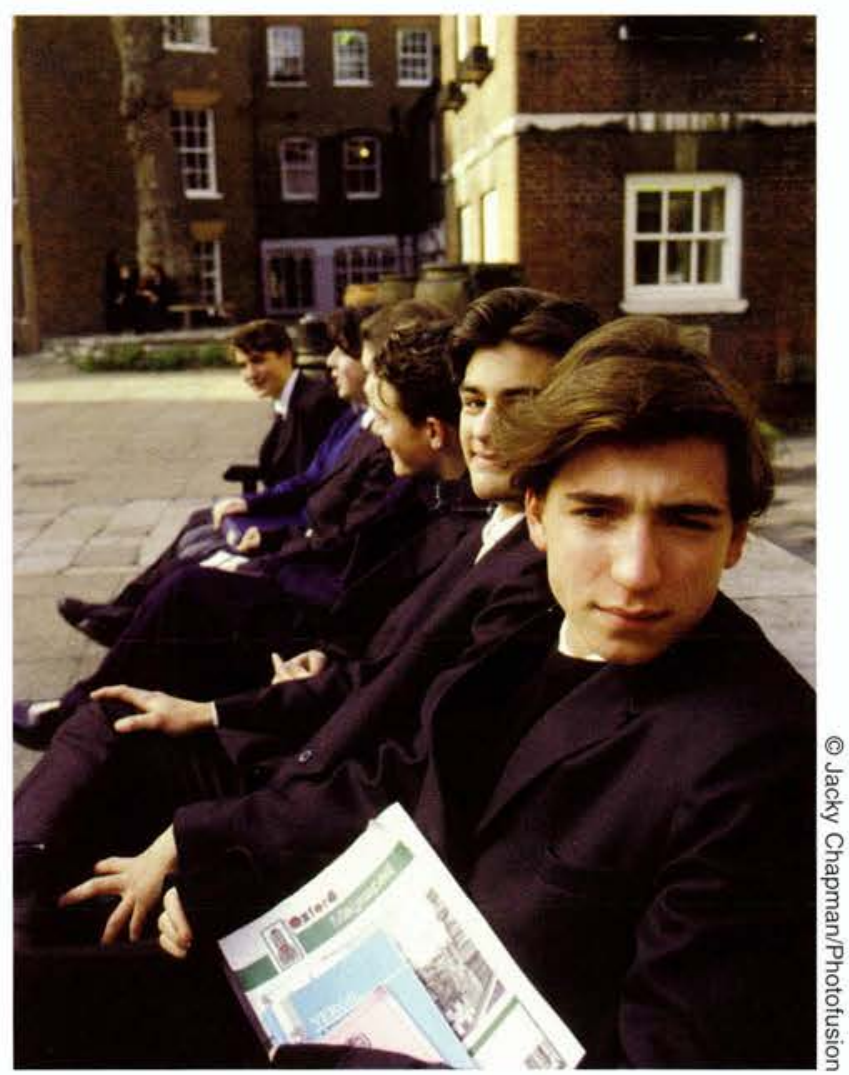

"Your pupils, your friends... Not a bad public that." rigorous quality and competency inspections, often used as precursors to reform, and of course, performance league tables.

In 1984 our school amalgamated with another school, and teachers had to travel miles from one site to the other during their working day. Parents and children had to travel too. We lost many of the children from our traditional primary feeder schools. Their parents understood the likely disruption to learning that this splitsite arrangement could cause.

During the recession we painted our own classrooms. Then came the rise of the sixth-form college, the introduction of technology, reforms to the exam system and, of course, the need to meet the cultural and social changes that were sweeping Britain at the time Nobody entering the profession in the 1970 s could have foreseen the changes that would take place in schools over the next two or three decades. My school went into decline. Soon it will close. Another school in the borough is about to be bulldozed, to make way for a sports academy.

$I$ admire people who give up other careers to enter the classroom. They feel they have something to offer today's schools, even though many of these, like mine, have become trapped and impoverished within the new 
social geography of Britain. It is a statement on what drives teachers: hope, enthusiasm, a desire to contribute.

But teaching also demands endurance. Recently on radio I heard a journalist, Steve McCormack, speak about his experience when he left his job to become a maths teacher. There were "magic moments", but the sheer volume of work was one of the things that got to him. Then there was the attitude of students, demotivated, inattentive and hostile. Steve left after two years.

The public have always had a general respect for the teaching vocation, but do they really appreciate the day-to-day achievements against the odds or the anxiety that many teachers experience when the classroom reaches boiling point? A conversation about teaching in A Man For All Seasons comes to mind.

"Your pupils, your friends, God. Not a bad public that..... Oh, and a quiet life."

I wonder if Thomas More ever came to regret not continuing his career in the classroom. For us who have taught, who thrive in working with pupils and colleagues, there is an empty space, a hankering to belong fully, not in the "real world" as is often said (there is nothing more real than a group of school kids, whether eager or disaffected), but in the world of successful enterprise, of recognition. To be not just respected, but admired; to be not just admired, but envied.

Pay was never a leading issue in my book, even if I had always been keenly aware of the inadequacy of teachers' salaries. Actual funding of schools and investment in more teachers are more important. Financing was never sufficient, particularly after power went to the local authorities. Recent suggestions in Britain that teachers could take classes of as many as 80 pupils by introducing redundant civil servants into the classroom as assistants hardly inspire admiration or optimism.

\section{Working with a group of youngsters, setting targets, expecting to better last year's results: this is where the job satisfaction comes from.}

So, where does the satisfaction come from? My wife watches me talking to ex-pupils I bump into in railway stations and supermarkets. "There's your job satisfaction", she says. "Look what you have given to the community." She's a medical secretary, working in a world where service to the community is important.

Nevertheless, when asked, "Was it worth it?", I have to think. Lying in theatre with a cardiac catheter attached to my heart, I would have given you a pretty crisp answer to that question. Now I am feeling fine. I work half-days. I have time to write and reflect.

Early on, long before the coursework revolution happened, it became clear that my pupils were getting consistently good exam results, and in the year I became Head of English, our A-level results were reportedly the best in London.

Clearly, the professional who finds a particular skill, whether in the classroom or on the sports field, in art or science, or as a genuine "kids' teacher", is in with a chance of making a difference. This is where the job satisfaction comes from, working with a group of youngsters, setting targets, expecting to achieve those results, and being motivated by the drive to equal or better last year's results. I think that's what kept me going and what even today sends me rushing to make my Liverpool Street connection and teach in a small faith school on the other side of London.

I don't know if this type of job satisfaction will hold in the new generation of schools with classrooms designed to hold several scores of pupils, where children are taught extended moral contemplation for a relativist society in which decisions are divorced from rules. Put this alongside staff shortages, drug testing, and inspections with two days' notice, and see how many hours sleep you get.

People who leave another profession to teach are usually sufficiently wellinformed to know what they are doing. To younger teachers I would say: look out for signs such as a school that cannot hold onto its talented staff. The dynamic deputy head who leaves after two years is making a statement about the future of the school. Look for a work ethic among the students, a collegiate atmosphere in the staff room, the sense of a corporate teaching staff. Look at the trend in exam results. And think of future careers too. It may be that after ten years in the classroom you might want to move on.

So, it was the single skill that made it worthwhile for me. Kyra Hollis in David Hare's play Skylight says, "And that's it, that's being a teacher. One private target, and that's enough."

It was enough for me.

\section{References}

- BBC (2004), "Is becoming a teacher really a way out of the rat-race?", 18 February 2004. available on the Internet on BBC Radio 4 Today, "Listen Again" audio archives

- Bolt, Robert (1960), A Man for All Seasons.

- Davies, Nick (2000), The School Report. Vintage Original.

- Hare, David (1995), Skylight.

"Kieran Clarke spent the best part of 40 years as a secondary school teacher in the UK. He was head of English and Modern Languages at a large boys' school in Blackheath, and later taught at Yesodey Hatorah Boys in Stamford Hill. Now officially retired, $\mathrm{Mr}$ Clarke, who holds a degree in psychology, continues to guide school students towards exams and teaches literacy to adults. The views expressed in this article are those of the author and do not necessarily reflect those of the OECD or its member countries. 


\section{That sense of belonging}

Education at a Glance 2004

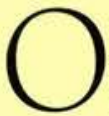
wnership, participation, stakeholder involvement: these form the jargon of today's open policymaking with civil society. But what about school kids?

Pupils and students are stakeholders in their own education, as well as in their own futures. Curiously, there has been less attention paid to how students feel about being in school, and about the extent to which they belong to the educational process they enter every day.

\section{Yet, such a question could be} crucial. According to the latest edition of Education at a Glance, a sense of belonging, or "fitting in", may encourage or discourage students' participation in school, as well as how they do academically, and eventually in choosing a career. Nearly a quarter of all 15-year-olds surveyed responded negatively about how well they fit in at school. Students most reported feeling like outsiders in Korea, Poland and Japan, followed by Belgium and France, whereas students in Austria, Sweden and Switzerland reported a particularly high sense of belonging.

Education at a Glance reports that in the two weeks before this survey was conducted, one in five students had missed school, arrived late or skipped classes.

Disengagement and eventual dropping out of school may have an economic impact down the road, as Education at a Glance shows a link between levels of education and earnings: those students who further their education generally earn substantially more and in more secure jobs than those with less schooling.

Education at a Glance, the OECD's annual compendium of education statistics, provides a basis for

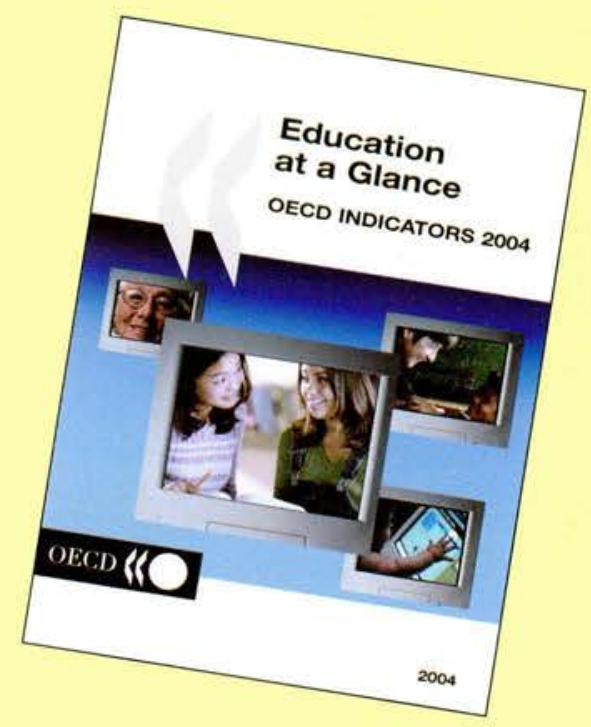

educational policy debate and decision-making.

This year, in addition to several new indicators on literacy skills, student engagement and admission policies, the report focuses on the outcomes of learning, financial resources, access issues, and the learning environment.

ISBN 9264-015671. See the New Publications pages or www.oecd.org/bookshop for ordering details.

\section{Frankie.org by Stik}
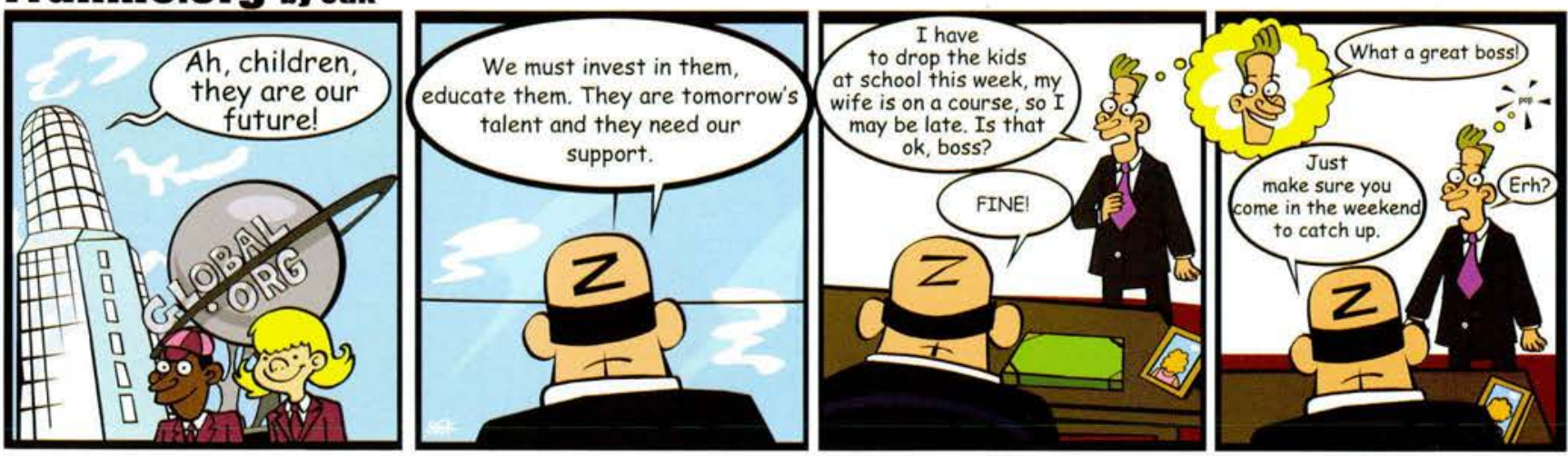

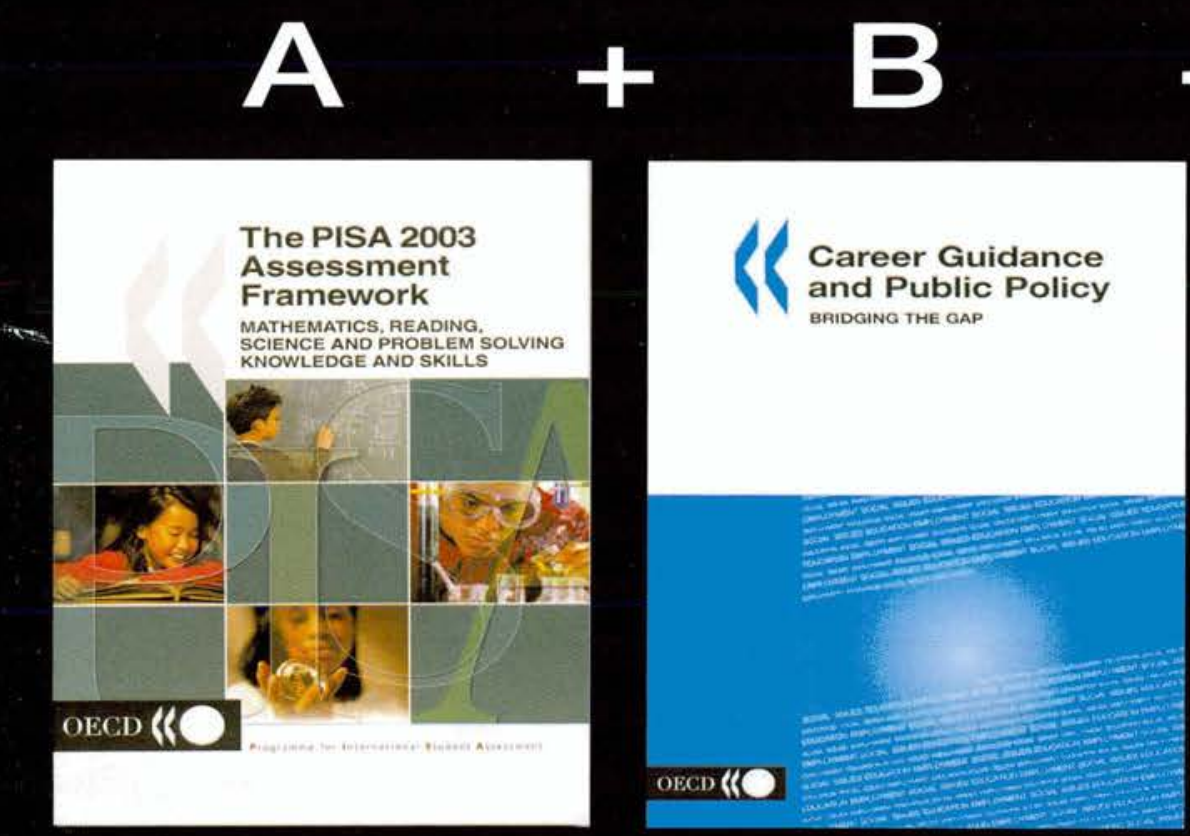

-
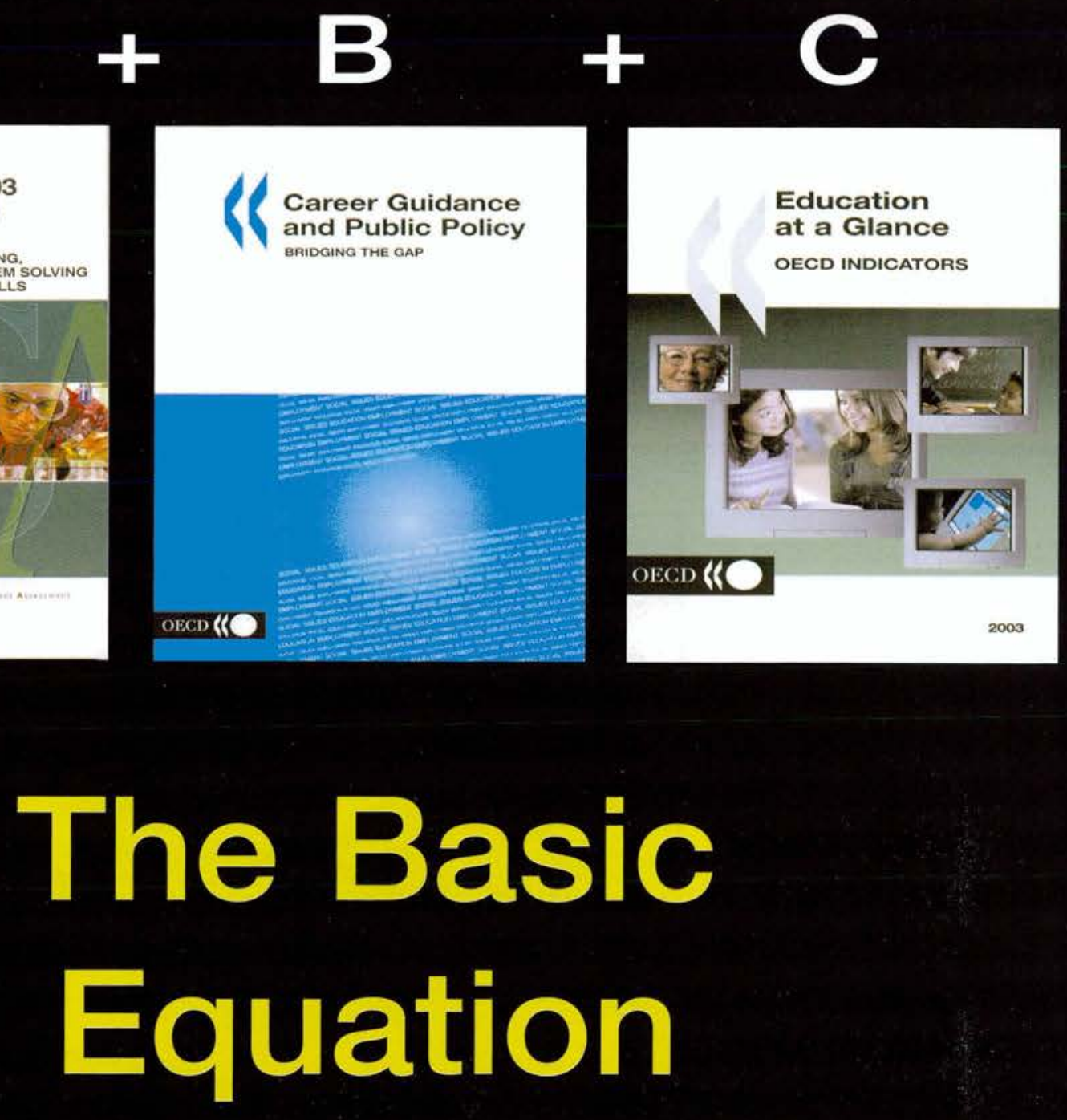

\section{Read OECD publications on education} www.oecd.org/bookshop

To be the first to know about new OECD publications on education,

sign up for OECDDirect, our free e-mail alert service: www.oecd.org/OECDDirect 


\section{Funding the fight against global poverty}

Helmut Reisen, OECD Development Centre

Taxes, philanthropy and financial markets could all become new sources of funding to help finance development and meet the Millennium Development Goals. But donors should be aware of their pitfalls too.

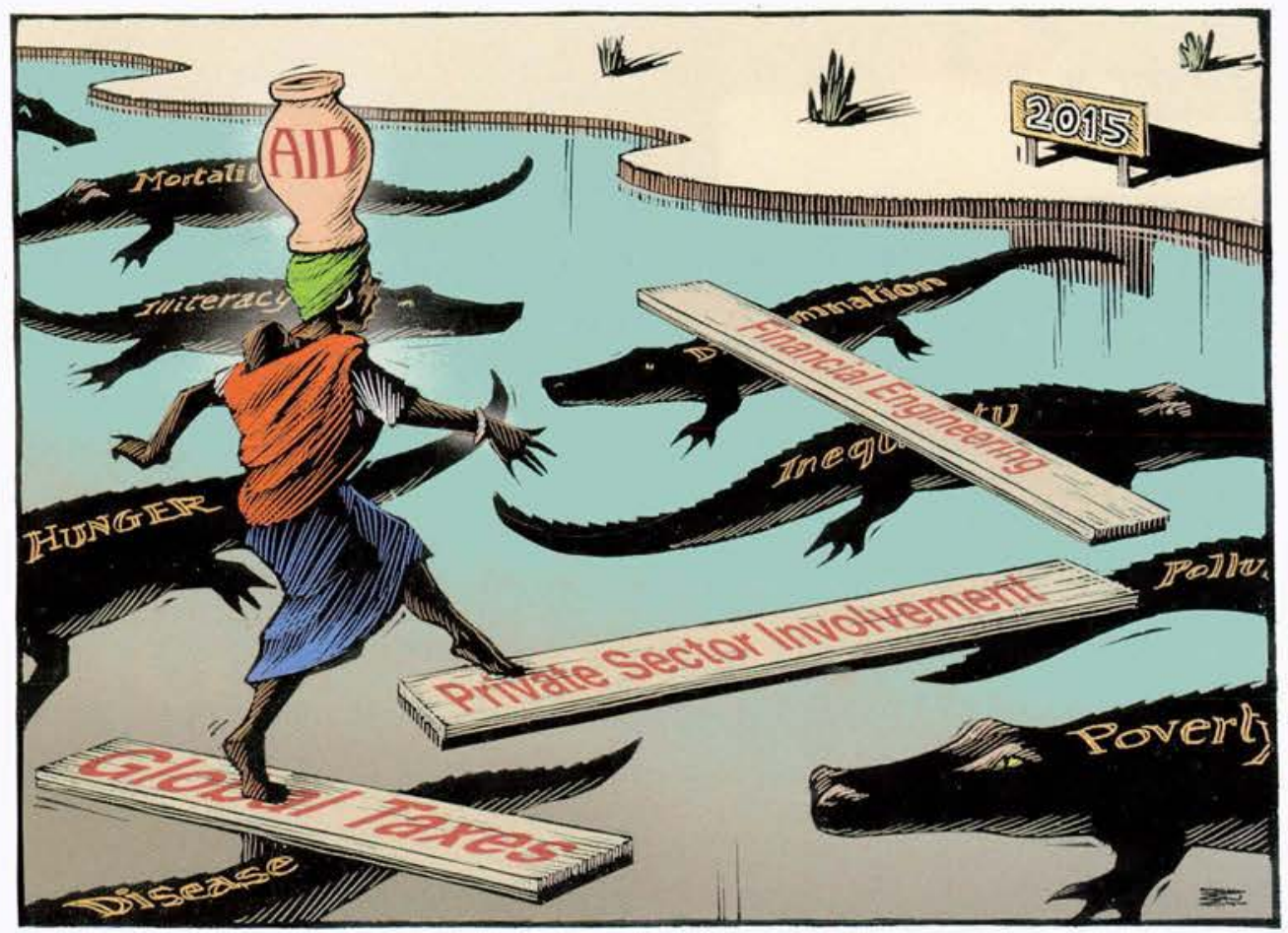

$\mathrm{O}$ n 20 September, several world leaders met in New York in response to an invitation from President Lula of Brazil to discuss possible new ways of financing the fight against world hunger. The meeting was part of the drive to meet the so-called Millennium Development Goals adopted just four years earlier, but which are now in danger of being missed. Not that anyone has ever objected to the goals; on the contrary, experts, aid activists and the general public alike, as well as political leaders the world over, hailed them as a breakthrough, with clear targets for fighting poverty, hunger, disease, illiteracy, environmental degradation and discrimination against women. But how time flies. Can we make up ground and meet the agreed deadline of 2015? Yes, though as those at the New York meeting would agree, more funding may be needed. How much is not clear, yet many say as much as $\$ 50$ billion per year, which is roughly the total of aid spent by rich-country donors now.

Sure enough, recent pledges by donor countries, in Monterrey and elsewhere, have improved prospects for higher aid flows, but still leave the annual target to achieve the MDGs underfinanced by some $\$ 25$ billion. The simplest solution is to raise aid further. However, budgets are tightening, which means new sources of development finance must be found if governments are to be sure of keeping their pledge to the world's poor.

What are the options? Broadly, there are three: global taxes; private-sector contributions; and financial engineering.

Take global taxes first of all. These have widespread public support, notably among civil society groups, in part because they seek to finance a 
global public "good" (development) by imposing a tax on a global "bad", such as speculative international finance, pollution or the arms trade. Any new tax would, of course, have to be easy to collect and hard to evade, but if it generates spin-off benefits other than revenues, such as a cleaner environment, then a tax would not only be worth it, proponents say, but may even be a better way to finance development than traditional aid.

Already today, "green" taxes yield on average $2.5 \%$ of GDP in OECD countries. However, a global environmental tax seems too distant a prospect to help us fund the MDGs in time. Nor are rich countries showing much sign of eagerness to pencil in proceeds from their new carbonrelated tax for aid purposes.

Another possibility is to tax currency transactions. Such a tax was originally proposed in 1927 by James Tobin, a Nobel Prize winning economist. Although Mr Tobin's idea was to combat exchange-rate volatility, the tax now appeals to NGOs and some governments as a way to generate funds for development. After all, even a very small rate on such a large tax base as the foreign exchange market would yield large returns; indeed, a rate of just $0.01 \%$ applied on a global scale would generate an estimated $\$ 17-19$ billion in revenue.

There are downsides though. First, the tax would have to cover multiple transactions, including hedging activities. Each transaction would be taxed, but the overall size of the tax base of daily foreign exchange transactions would shrink. In any case, the tax base for global financial capital may simply be too mobile to be relied on for financing the MDGs.

As for taxing arms dealing, even if the legal and documented trade in arms (worth around $\$ 50$ billion per year) was unaffected by taxation, a $5 \%$ tax

\section{Budgets are tightening, and new sources of development finance must be found if governments are to be sure of keeping their pledge to the world's poor.}

would not yield more than $\$ 2.5$ billion annually. Also, the tax could backfire, so to speak, since higher taxation could stimulate more illicit arms dealing.

If a tax alone might not help meet the MDGs, what about encouraging more private funding? The United Nations Children's Fund (UNICEF) covers around a third of its income from NGO and private-sector contributions, according to its 2003 annual report. Programmes like the Global Fund to Fight AIDS, the Vaccine Fund and the Global Environment Facility are administered and financed by coalitions of governments, international organisations, private enterprise and civil society. The trouble is, though they might serve to finance specific urgent problems, they may lead to a less coherent response to global development by duplicating existing structures and substituting official aid, and so not actually adding much extra. Private sector contributions would probably not be enough to make up the financing shortfall of the millennium goals, and even if a huge pool of donors were built up via firms and charities, it would take years to make an impression.

Financial engineering, which is what the UK government's International Finance Facility (IFF) idea effectively is, would stand a better chance of providing the additional funds needed to reach the development goals. The finance facility would be built on a series of pledges by donors (each lasting 15 years). On the back of these pledges (its assets) the IFF would issue bonds in its own name (its own liabilities). The UK plan could be improved, though: real liquid public assets would bolster the credibility of the facility, and lower prospective spreads on the bonds it would issue, making them less risky. The demand for these bonds issues might also be enhanced if they were in the form of a lottery ticket, perhaps modelled on low-risk schemes currently in operation in Ireland and the UK.

The main advantage of the finance facility is that it could boost aid to as much as $\$ 100$ billion per year during the crucial $2010-2015$ period. And it emphasises grant finance rather than loans to the recipient countries, so relieving some pressure on poor country governments. Also, because donor co-ordination would take place through existing aid delivery channels, poor countries would not have to face myriad donors and regulations.

Global taxes, private charities and financial markets all have their advantages, so rather than choosing a single one, governments will probably want to pursue a combination of innovative funding approaches. This could well bring the Millennium Development Goals within reach, since more choice should stimulate the supply of more reliable funding.

\section{References}

- OECD (2001), Environmentally Related Taxes: Issues and Strategies, November 2001, OECD, Paris.

- OECD (2004), Development Co-operation Report 2003, OECD, Paris.

- OECD (2003), "Philanthropic Foundations and Development Co-operation", DAC Journal Vol, 4 No. 3, OECD, Paris.

- Reisen, Helmul (2002), "The Tobin Tax: Can It Work?", OECD Observer No 231/232, May, OECD, Paris.

- Reisen, Helmut (2004), "Innovative Approaches to Funding the Millennium Development Goals", OECD Development Centre Policy Brief No. 24, OECD, Paris. 


\section{Counting on numbers}

Who would question the value of numbers? They can add credibility to an argument, clinch a deal, or simply illuminate an issue. But they can also deceive, through misreading or even manipulation. Can we really rely on the statistics we read? In the build-up to a major international forum on "Statistics, Knowledge and Policy", to be held 10-13 November in Palermo, Italy, we asked Enrico Giovannini, the OECD's chief statistician, for an "unofficial" view.

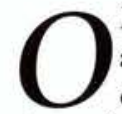
ECD Observer: The public and the media in Europe often complain about official data, for instance, that prices appear to be rising faster than government figures show. How would you explain this gap between public perceptions and official data?

Enrico Giovannini: This is an old story. Ten years ago, the Boskin Report showed that the consumer price index (CPI) in the US was overestimating inflation, and urged statisticians to improve their methods. Now, consumers living in euro-area countries believe that today's inflation figures underestimate reality.

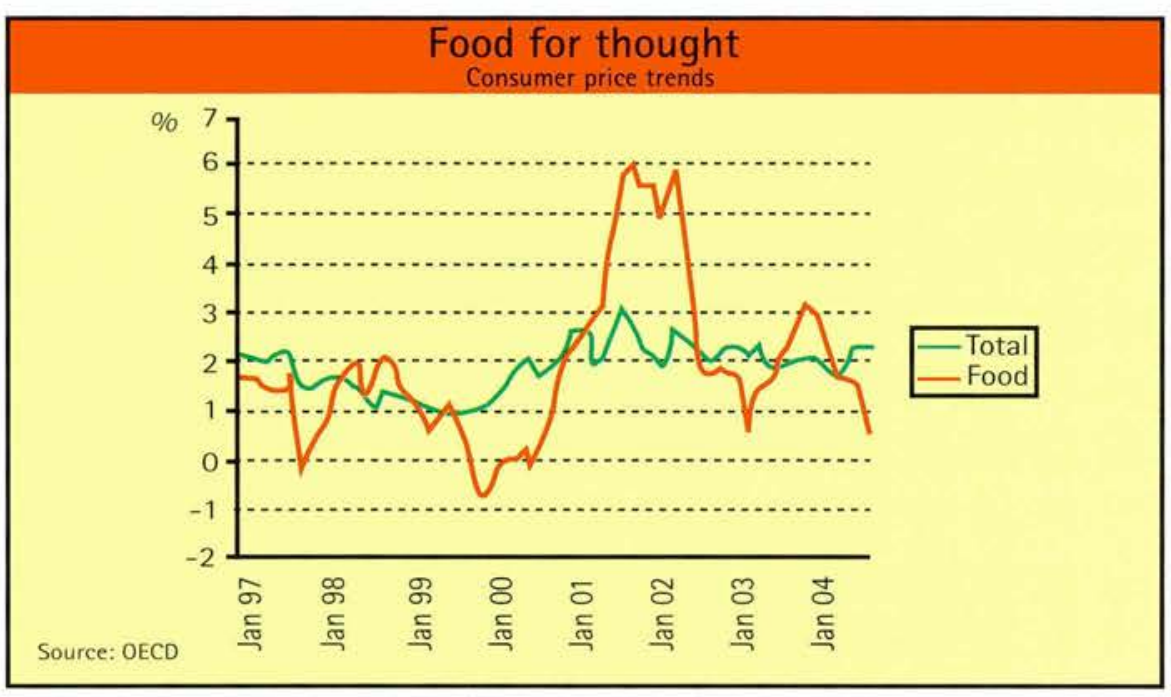

If you compare the "official" inflation with the so-called "perceived" inflation rate measured by opinion surveys, you will see two well-aligned curves until 2002, when the euro came in. But after that, the curve for perceived inflation rises more steeply than the official one. Now, is it possible that a system based on collecting hundreds of thousands of individual prices for each country and that is scrutinised by the IMF, Eurostat and the OECD could fail, while the experience of shoppers buying what is probably a limited range of goods and services, and probably bought in one city, provide a truer picture? My answer is no.

If we exclude the existence of an international organisation conspiracy, the only possible explanation for the difference regarding the euro is that consumers must confuse changes in prices between different goods with the average level of prices generally. In other words, just because a weekly shopping basket of food seems more costly does not mean there has been a rise in the overall price level, which may include furniture, computers and so on. With the introduction of the euro, some prices, especially of some frequently bought items, rose more sharply than others. This made it more difficult to assign correct values to the new notes and coins. According to some news reports, households faced unusual liquidity constraints before the end of each month and naturally they blame inflation. But how many of them accept that they might simply have spent more than usual because of the switchover? It is not easy to understand prices in a new currency, and overspending is a risk.

If there was collusion, it was in the media, which delighted in exaggerating the incidence of "local" price jumps. In herd-like fashion, this added further price pressure, even among those producers who had avoided raising their prices in the first place.

But could the experts be getting it wrong? For instance, couldn't a price index place more weight on bread and banking charges, and less on the falling cost of technology? 
For a start, if anyone dislikes unreliable statistics, it's the statisticians themselves. It's in our nature to want to improve them. After the criticisms made by the Boskin Report regarding the US price index, all countries began to update the weight structure of their indexes. In 1998, when I was Director for Economic Statistics at the Italian Statistical Institute, we decided to update them yearly, for instance.

On the other hand, there are some differences in household spending, depending on income level, sociodemographic conditions, etc, but they are not large enough to
You are hosting a major international forum on statistics, to be held in Palermo, Italy in November. What do you expect this conference to achieve?

We see the forum as a unique opportunity to bring statistics to the centre of national policy debates, by adding an international perspective. We live in an information-rich world, and there is a real risk of confusion. Do we really know whether society as a whole is improving or declining? My hope is that by identifying some key indicators to assess country performances, taking into account economic, social and

\section{Just because a weekly shopping basket of food seems more costly does not mean there has been a rise in the overall price level.}

explain wide differences in overall inflation rates. In some countries, consumer associations have estimated a "true" inflation at 3 or 4 times higher than the official rate. But there is no way of obtaining such results using reasonable weight structures. Also, what would be the aim of measuring separate inflation rates for 10 or 20 categories of households? Such an approach could be useful to analyse the impact of the euro on income distribution, but they cannot be used separately to disprove the overall inflation rate.

But the real clinching point is this: let's imagine actual inflation had been three or four times higher than the officially published rate. In that case, households' disposable income in real terms would have plummeted, hurting consumption, employment, and so on. Euro-area countries might have tipped into a serious recession! This did not happen. Overall, it seems that official figures are broadly correct. environmental aspects, we can find clear answers. And we can then use those indicators to build a true knowledge base for better action.

The selection of any credible "key indicators" must involve society broadly - academics, NGOs, business and the media, and so on. Statistical offices will gather the data and communicate them regularly. Technical and policy questions, best practices, useful initiatives: all these issues will feature at the Forum. We expect results. After all, more than 150 world-class speakers from 30 countries and 12 international organisations will be present. As George Washington said in 1790: "Knowledge is in every country the surest basis of public happiness". Reliable statistics can help us build such knowledge. This is what the Forum is about.

For more on the OECD Forum on

Key Indicators, consult:

www.oecd.org/oecdworldforum.

\section{Forcing spam back}

W Thether you are at work or at play, spam is a bane for anyone using e-mail and the Internet. It spreads junk mail and viruses, and betrays user trust online. It reduces productivity and pushes up the costs of doing business. It also undermines privacy rights and consumer protection laws. The trouble is, because this unwanted, unsolicited junk e-mail is often sent from discreet places of origin to large numbers of recipients around the world, it is very hard to control or stop. A battery of measures and initiatives exist to fight it, from tough rules of practice to smart technology, but no single approach seems to be working.

There are steps that can help, though, and one is better international co-ordination. That is why in August, the OECD set up a task force to link the efforts of government, business and civil society in the most comprehensive, strategic and inclusive response to date to the problems posed by spam. The OECD Task Force on Spam includes participants from all $30 \mathrm{OECD}$ countries, the European Commission, business leaders and civil society. One of its first steps was to launch an anti-spam toolkit.

For Tom Dale, who heads the task force, spam is "now clearly used for significant criminal activity" and "the Toolkit is a fast-track approach (...) to assist the development of cross-border enforcement against spammers."

The Toolkit will eventually include a spam regulation handbook; an examination of the relevant self-regulatory arrangements which exist at industry, national or international levels; and an analysis of existing and emerging technical measures against spam, including authentication technology. There will be tips for users on how to protect themselves from spam, including how to avoid "phishing", when spammers use fake e-mails to encourage Internet users to divulge confidential financial data.

The Task Force welcomes contributions to the Toolkit. Comments can be sent to spam.project@oecd.org. More information can be found at www.oecd.org/sti/spam. 


\section{The OECD in a changing world}

\section{Highlights from the Chair's summary}

\section{OECD Ministerial CounCIL MeEting 13-14 May 2004}

$\mathrm{M}$ exico joined the OECD in 1994 and this year, on the 10th anniversary of its accession, had the honour of chairing the OECD Ministerial Council Meeting. Ministers from all OECD and some non-OECD countries attended, and there were consultations with representatives from business and industry, trade unions and civil society more broadly, notably at the fifth OECD Forum held on 12-13 May (see next edition).

The Chair's summary report covers the wide range of issues discussed by ministers at the annual summit: the economic outlook, ageing populations, health financing, and world trade and development. On OECD current work, ministers warmly welcomed the recently revised OECD Principles of Corporate Governance and encouraged "their wide dissemination and active use". They also praised the results of the three-year project on sustainable development, pointing out that "governments could achieve the same results in protecting the environment at significantly lower cost through the greater use of more cost-efficient instruments in many countries." They adopted recommendations for further work on sustainable development in the OECD. Ministers also paid tribute to the significant achievements of the Financial Action Task Force over recent years in combating money laundering and terrorist financing, and welcomed the decision of their FATF colleagues to extend the mandate of the task force for a further eight years.

On the global economic outlook, the feeling was that while "the fundamentals are healthy for future growth", appropriate policies are needed to make the expansion robust and durable. That means interest rates rising in countries furthest into recovery, for instance, while most countries recognised the need for fiscal discipline, and "deficits now need to be rolled back".

Ministers were conscious of risks associated with rising oil prices. They also looked at the issue of outsourcing, which they said was "in itself (...) part of the continuing trend towards international integration, and should be welcomed because it leads to higher productivity and real incomes." Nonetheless, they concurred that at least in the short term,
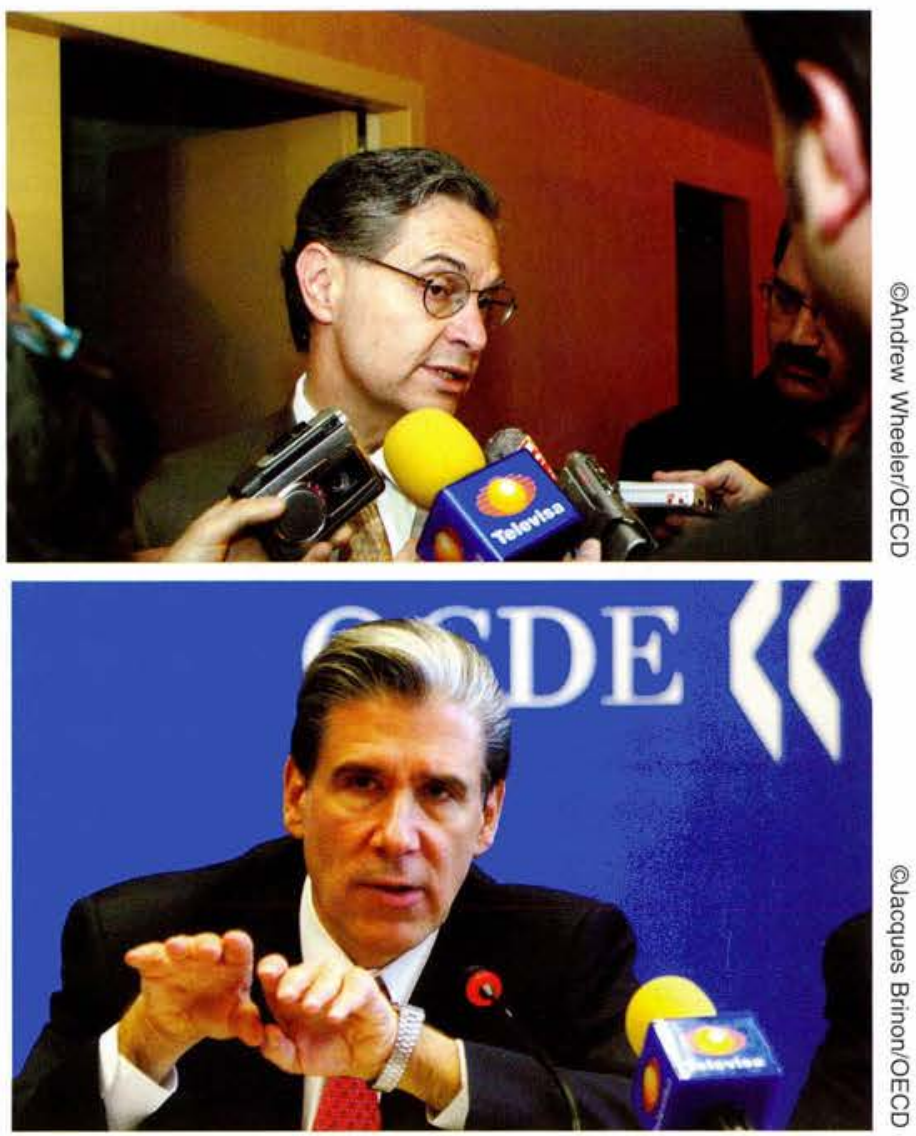

Mexico leads the way: Foreign Affairs Minister Luis Ernesto Derbez (top), who chaired the Ministerial Council, and Health Secretary Julio Frenk, who headed the Health Ministers Meeting.

OECD countries needed policies to help people adjust to their new environment when they are dislocated because of outsourcing.

Population ageing may be a good thing in that people are living longer, healthier lives, but OECD ministers are aware of the policy adjustments that are essential to sustain growth and healthy public budgets. "There is much to do and, in many countries, not much time to get it done", the chair's summary points out. Retirement patterns must change, and more done to link retirement ages to life expectancy. Programmes should not encourage older workers to leave the labour market prematurely, though opinions among ministers differed on the role of tax/benefit policies.

Absorbing a large supply of older workers would not be easy in many countries without more dynamic labour markets. Ministers noted the importance of upgrading skills, while some stressed that attitudes among employers and older workers would need to change. 
Another challenge for governments is how to fund healthcare, particularly as more people live longer. $O E C D$ health and finance ministers are concerned that this growing demand and further technological advances in modern medicine will increase pressure on public sector budgets. Maximising value for money has become a focus. This does not necessarily mean spending cuts, and a number of ministers recognised that scope existed for some increase in public spending on healthcare. But they also agreed on the need to ensure cost-effectiveness, as well as on individuals taking greater responsibility for their own health. Many households could pay a larger share of healthcare costs, though low income households and the chronically ill had to have access to healthcare.

Controls, such as budgetary caps, have successfully contained costs in many countries, but care had to be taken to minimise negative effects on the efficiency and quality of healthcare. Also, ministers' views differed on the role of private insurance. Some argued that it could offer greater consumer choice and help to limit public expenditure, but others doubted that private health insurance helped to contain costs and were concerned that increasing its role would put universal coverage at risk.

\section{There is no substitute for the multilateral trading} system, ministers agreed, and were determined to reach basic agreements on frameworks for key issues in the current round of trade talks under the so-called Doha Development Agenda. Agricultural reform holds the key to progress. There have been encouraging signs, but much work needs to be done on export competition, domestic support and market access. A focus of discussion was trade and development, where much has been accomplished since the launch of the Doha round, but further progress is needed.

Reform not just in OECD countries, but in the organisation's own secretariat was also the subject of some discussion. All international organisations are under pressure to perform and stay relevant to their stakeholders in today's fast changing world. Ministers welcomed the recent agreement to a number of measures concerning the future role and governance of the OECD, including a strategy for enlargement and for strengthening relations with non-OECD economies; the establishment of a new decision-making method for special cases; and the amendment to the scales of contribution by member countries to the budget of the organisation. Some countries called on the OECD to develop a more strategic approach to its work with non-member economies, including in the Middle East and North Africa, in a bid to increase its global impact.

For more information on the OECD Ministerial Council Meeting, please consult www.oecd.org/mcm 2004.

\title{
Healthcare
}

\section{An economic driver}

\author{
The OeCD Health Ministers Meeting, 13-14 May 2004
}

JULIO FRENK, HEALTH SECRETARY OF MEXICO AND CHAIR OF THE OECD HEALTH MINISTERS MEETING

1

The value of shared learning and mutual understanding: this was a key message of the OECD Health Ministers Meeting last May. The agenda showed the myriad areas where economic analysis can enrich policy design: from quality, efficiency and cost-effective provision, to the economics of prevention and the incentives for innovation.

The meeting was an opportunity for ministers to discuss different perspectives and experiences, and the importance of bringing together health and economics for the benefit of policymaking was in evidence. There is no single recipe for addressing the complexities of health sector reform. Rather, the availability of a broad menu of options to ensure the financial sustainability of health systems through more emphasis on preventive care greatly enhances the policy process.

There was a lively discussion on the role of innovation and its capacity to ensure that advances in science are translated into benefits for patients. All agreed that those in greatest need should have access to healthcare and the latest medical technologies.

A memorable highlight of the meeting was the joint discussion between ministers of health and finance. Such encounters between these ministries are unusual for most countries, and this was their first-ever coming together at the OECD. It was another excellent opportunity to confirm the significant role health systems play in our economies. The discussion went beyond the traditional focus on cost-containment to a more profound analysis of the many ways health system performance and economic growth interact. And it underscored how much of what governments do is interrelated, cutting across disciplines, and how horizontal approaches that harness different expertise to solve problems can improve our knowledge and policymaking

The OECD 2004 Health Ministers Meeting was a landmark in international cooperation and contributed to a better understanding of the central role of health in the development agenda. Mexico has benefited greatly from this exchange and we look forward to contributing to future work. Today, more than ever, economic and social policy must be treated as two sides of the same coin.

\section{References}

- Frenk, Julio (2004), "Health and the economy: A vital relationship", in OECD Observer No 243, May 2004.

- For more on the health ministerial meeting, please see www.oecd.org/health. 


\section{Calendar of forthcoming events}

Please note that many of the meetings mentioned are not open to the public or the media and are listed as a guide only. All meetings are in Paris unless otherwise stated. For further information, consult the OECD website at www.oecd.org/media/upcoming, which is updated weekly.

11-13 World Knowledge Forum, annual forum exploring the challenges of a knowledgebased society, organised by Maeil Business Newspaper. Seoul, Korea

SEPTEMBER - highlights

22 Renewable Energy, meeting organised by the OECD Round Table on Sustainable Development

22-24 International Entrepreneurship Forum, organised by the OECD Local Economic and Employment Development Programme (LEED).

23 Sustainable Mobility, meeting organised by the OECD Round Table on Sustainable Development.

\section{OCTOBER}

2-3 Annual meetings of G10 Ministers, the World Bank Group and the International Monetary Fund Washington, DC, USA

4-7 Youth Employment Summit (YES): Evaluating Global Progress on Youth Employment. Hosted by the Government of Mexico. Boca del Rio, Veracruz, Mexico.

4-8 Annual debate with the Parliamentary Assembly of the Council of Europe. Strasbourg, France.

5 Financial Education, Pensions \& Insurance Issues in the Baltic States, organised by the Directorate for Financial and Enterprise Affairs. Riga, Latvia.

6 Business Performance and Intellectual Assets, forum organised by the Directorate for Science, Technology and Industry.

7-8 Using New Tools for Decision-Making Impacts on Information, Communication and Organisation, meeting of the Network of Senior Officials from Centres of Government. Istanbul, Turkey.

8-9 Latin American Corporate Governance Roundtable meeting organised by the Directorate for Financial and Enterprise Affairs. Rio de Janeiro, Brazil.

11-12 Trade in Educational Services: Building Capacity for Education through Crossborder Provision, forum organised by UNESCO and the Directorate for Education. Sydney, Australia. Forum organised by the Directorate for Financial and Enterprise Affairs. New Delhi, India. Eastern Europe, Caucasus and Central Asia Countries on Environmental Strategy, organised by the Environment Directorate: Tbilisi, Georgia.

25-26 Challenges and Opportunities of Developing Broadband in Rural and Remote Areas, workshop organised by the Directorate for Science, Technology and Industry. Porto, Portugal.

28-29 Restructuring of Tourism Destinations and Enterprise Dynamics, seminar organised by the OECD and the Tourism Ministry of Portugal. Lisbon, Portugal.

31-3/11 ICT and Educational Property Management, seminar organised by the Education Directorate and the Canadian government. Montreal, Quebec. Mr Recep Rayyip Erdogan.

28 October - President of the Republic of Finland, Ms Tarja Halonen.

\section{NOVEMBER}

2-3 Asian Corporate Governance for Financial and Enterprise Affairs. Seoul, Korea.

3-4 Trade and Structural Adjustment, ESCAP. Bangkok, Thailand.

4-5 Environmentally Sustainable Transport, workshop organised by the Environment Directorate and hosted by Berlin, Germany.
19-21 International Investment, OECD Global

21-22 Meeting of Environment Ministers for

Visits: 21 October - Prime Minister of Turkey, Roundtable, organised by the Directorate

0-13 Statistics, Knowledge and Policy, OECD World Forum on Key Indicators, organised by the Statistics Directorate. Palermo, Italy.

11-12 Global Forum on Sustainable Development, organised by the Environment and the Development Cooperation Directorates.

24-26 Promoting Economic Growth across Europe, 7 th Central European Initiative Summit, with participation of the OECD Programme on Local Economic and Employment Development (LEED). Portoroz, Slovenia.

25-26 Knowledge Based Regional Development and Innovation, conference organised by the Public Governance and Territorial Development Directorate. Florence, Italy. OECD Economic Outlook published.

\section{DECEMBER}

1 World AIDS Day.

2-3

Environmental Enforcement and Compliance, high-level conference of the Global Forum on Sustainable

Development, organised by the Environment Directorate. OECD Global Forum co-organised by the Trade Directorate and the United Nations the German Federal Environment Agency.
Global Forum on Agriculture, organised by the Directorate for Food, Agriculture and Fisheries.

6-17 Climate Change Summit, 10th Session of the Conference of the Parties (COP $10)$, organised by the UN Framework Convention on Climate Change. Buenos Aires, Argentina.

9-10 Senior-level meeting of the Development Assistance Committee. 


\section{Pricing risks}

The Security Economy

High-tech security tools may well be making the world safer, but they are also a lucrative business. Estimates from The Security Economy put the security industry's value at between US\$100 billion and $\$ 120$ billion worldwide, and growing. The largest share is accounted for by the US at $\$ 40$ billion, while in Germany the figure is approximately $\$ 4$ billion, followed by France and the UK at around $\$ 3$ billion each.

The Security Economy - a series of articles by international experts from government, business and academia - examines what is behind the demand for heightened security, and how markets and societies are responding. Although crime rates have generally diminished in OECD countries, the impetus of globalisation - with its freer movement of goods, capital and people - facilitates robbery and smuggling. The overall cost of crime is huge, estimated at roughly $20 \%$ of GDP in the US and around $7 \%$ of GDP in the UK.

Furthermore, the potential for large-scale damage from acts of terrorism has increased, says The Security Economy. Fear, secrecy and suspicion are becoming more pervasive, and are influencing strategies in business and government. Some see new technologies as the solution, whether to check identities or to track credit-card spending.

But what happens when security technology is put to other, more intrusive and controversial uses? The Security Economy warns that there is a growing tendency to use databases not just to sort and identify people, or to clock them in and out of work, but to profile them, sometimes without their knowledge, into categories of, for instance, potential lawbreakers or customers. The Security Economy addresses the social and policy implications of these risks.

The question is how to achieve the optimal balance between security measures and efficiency, as the costs of extra security may be high in the short and medium term, but to the extent that they prevent serious damage and disruption, the long-term benefits can be enormous. The Security Economy cites a new electronic manifest handling system proposed by US customs whose improved tracking of goods could save US importers some $\$ 22$ billion over 20 years, and the US government over $\$ 4$ billion. The goods may go through port more slowly, but they will be processed more securely, and more economically too.

ISBN 9264-10772X. See the New Publications pages or www.oecd.org/bookshop for ordering details.

\section{Clear, but not absolute}

\author{
Environmental Performance Review of Sweden
}

Sweden's good reputation for a clean environment may be deserved, but there are murky spots. True, it gained high marks in the recent OECD Environmental Performance Review of Sweden. It was one of the first OECD countries to cut its use of environmentally harmful chemicals, and is one of the few OECD countries on track to meet their commitments under the Kyoto Protocol to limit greenhouse gas emissions.

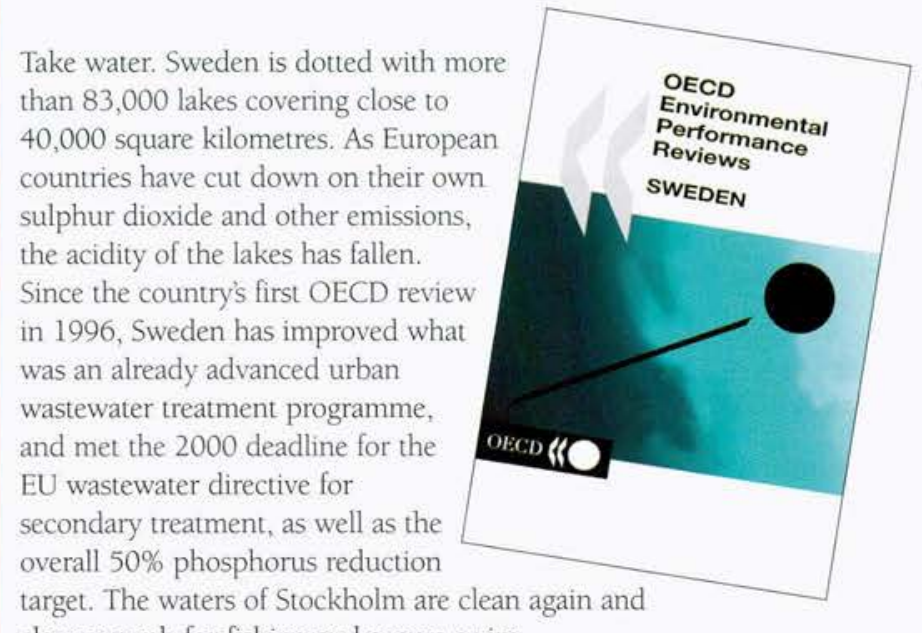

clear enough for fishing and even a swim.

But, as the second Environmental Performance Review of Sweden warns, its ambitious environmental quality objectives for water management, such as good quality groundwater, a balanced marine environment and healthy coastline (Sweden's is $2,700 \mathrm{~km}$ long), still need much attention, as do a number of EU water directives, such as further cutting nitrate concentrations.

Sweden is responsible for $21 \%$ of the total land-based leaching of nitrogen into the Baltic and Kattegat Bay, for instance. Contaminants, such as dioxin, once emitted by the pulp and paper industry, remain a problem and the consumption of both freshwater and marine fish is restricted. Old abandoned mines are a long-term source of heavymetal contamination in Swedish lakes. Furthermore, overfishing has reduced populations of cod and Baltic herring to dangerously low levels, the Environmental Performance Review reports.

Sweden has adopted cutting-edge environmental quality objectives and upped the ante on conservation legislation, says the OECD's Environmental Performance Review of Sweden. Yet its efforts need to be buttressed internationally. Indeed, without action, persistent organic pollutants drifting in from afar and the effects of climate change could yet lower the Arctic chill, and turn the renowned Ice Palace back into water.

ISBN 9264-108580. See the New Publications pages or www.oecd.org/bookshop for ordering details. See also the recently published Environmental Performance Reviews of Canada and Spain. 


\section{New publications, July to September 2004}

All publications are available in paper and electronic book format. This is a selected list. For more titles and overviews in different languages, please consult www.oecd.org/bookshop.

OECD in Figures

ISBN 9264017356

$96 \mathrm{p}, 35$ tables, 16 graphics

$€ 15 \$ 19 \quad 10 \quad ¥ 1,900$

OECD Observer supplement.

Key data on OECD countries

The Security Economy

ISBN $926410772 \mathrm{X}$

$158 \mathrm{p}, 23$ graphics

$€ 24 \$ 30 \quad\{17 \quad ¥ 3,100$

See review

AGRICULTURE AND FOOD

OECD Agricultural Outlook:

2004/2013

ISBN $926402008 \mathrm{X}$

$244 p, 15$ tables, 78 graphics

$€ 50 \$ 63 \quad$ £35 $¥ 6,400$

Agricultural Policies in OECD

Countries: At a Glance, 2004

ISBN 9264016031

148 p, 73 tables, 66 graphics

$€ 35 \$ 44 \quad £ 24 \quad ¥ 4,500$

Fish Piracy: Combatting Illegal,

Unreported and Unregulated

Fishing

ISBN 926401679$]$

$402 \mathrm{p}$

$€ 80 \$ 100 £ 55 \quad ¥ 10,200$

Challenges and Risks of Genetically

Engineered Organisms

ISBN 9264108777

224p

$€ 60 \$ 75 \quad\{42 \quad ¥ 7,700$

DEVELOPMENT AND AID

Creditor Reporting System on Aid Activities: Aid Activities in Support of HIV/AIDS Control

Co-edited with UNAIDS

ISBN 9264016775

$228 \mathrm{p}$

$€ 34 \$ 36 \quad £ 23 \quad ¥ 4,400$

The Making of Global Finance 1880-1913

ISBN 9264015345

$152 \mathrm{p}, 52$ tables, 14 graphics

$€ 24 \$ 30 £ 17 \quad ¥ 3,100$

ECONOMICS

OECD Economic Studies: No. 37

OECD Code 132003371P1

$\square$

口

口

\section{- Watch for these forthcoming OECD publications}

- Economic Survey of Canada (October 2004)

口 Revenue Statistics 1965-2003 (October 2004)

- Financial Market Trends 87 (October 2004)

- OECD Steel Outlook 2004/2005 (November 2004)

[ Economic Outlook No. 76 (December 2004)

210p, 22 tables, 74 graphics

Sold as subscription only:

Includes chapters on: Impact of Old-

Age Pension Schemes; Labour Force

Participation of Women; Enhancing the Cost Effectiveness of Public Spending.

OECD ECONOMIC SURVEYS

Each survey: $€ 35 \quad \$ 37 \quad £ 23 \quad ¥ 4,600$

\section{Germany}

ISBN 9264108408

- $128 \mathrm{p}, 13$ tables, 22 graphics

Special features: Improving the capacity to innovate. Should pension reform continue? Should special programmes for the East be phased out? How should labour market reforms proceed?

Euro Area

ISBN 9264106545

167p, 44 tables, 38 graphics

Special feature: Convergence. What

future for the Stability and Growth

Pact? How to reap the benefits from economic integration? What prospects for growth and inflation?

\section{Korea}

ISBN 9264016635

194p, 44 tables, 61 graphics

Special feature: Product market compe

tition and economic performance.

Russian Federation

ISBN 926401634]

170p, 53 tables, 31 graphics

Special feature: Sustaining growth.

Poland

a ISBN 9264016082

220p, 28 tables, 43 graphics

Special feature: Labour markets.

\section{EDUCATION}

Education at a Glance: OECD

Indicators 2004

ISBN 9264015671 460p, 100 tables, 80 graphics

$€ 49 \$ 61 £ 34 \quad ¥ 6,300$

See article.

What Makes School Systems

Perform?

ISBN 9264017712

$73 \mathrm{p}$

$€ 24 \$ 29 \quad\{17 \quad ¥ 3,100$

School Safety and Security: Keeping

Schools Safe in Earthquakes

ISBN 9264016694

244p, 31 maps

$€ 40 \$ 50 £ 28 \quad ¥ 5,100$

University Research Management:

Meeting the Institutional

Challenge

ISBN 9264017437

250p, 33 tables

] $€ 55 \$ 69 £ 38 ¥ 7,000$

Internationalisation and Trade in Higher Education: Opportunities and Challenges

ISBN 9264015043

250p, 50 tables, 15 graphics

$€ 50 \quad \$ 63 \quad £ 35 \quad ¥ 6,400$

EMPLOYMENT AND SOCIAL ISSUES

OECD Employment Outlook $2004 \square$ ISBN 9264108122

330p, 19 tables, 47 graphics

口 $€ 65 \quad \$ 81 \quad £ 45 \quad ¥ 8,300$

See article

Ageing and Employment Policies:

United Kingdom

- ISBN 926401621X

120p, 15 tables, 27 graphics

$€ 24 \$ 24 \quad$ f15 ₹2,900

Ageing and Employment Policies: Italy

ISBN 9264017038

$130 \mathrm{p}$

$€ 24 \$ 24 \quad £ 15 \quad ¥ 2,900$
Babies and Bosses - Reconciling

Work and Family Life: New

Zealand, Portugal and Switzerland $\square$ ISBN 9264108343

200p

$€ 29 \$ 36 \quad £ 20 \quad ¥ 3,900$

Income Disparities in China: An OECD Perspective

ISBN 9264017216

280p, 57 tables, 26 graphics

$€ 40 \quad \$ 51 \quad £ 28 \quad ¥ 5,100$

Benefits and Wages: OECD

Indicators

ISBN 9264015159

$80 \mathrm{p}, 35$ tables, 15 graphics

$€ 24 \$ 29 \quad £ 17 \quad ¥ 3,100$

\section{ENERGY}

Coming in from the Cold:

Improving District Heating Policy in

Transition Economies

ISBN 9264108203

$264 p$

$€ 52 \$ 65 £ 36 \quad ¥ 6,700$

Uranium 2003: Resources,

Production and Demand

Co-edited with the International

Atomic Energy Agency (IAEA)

ISBN 9264016732

292p, 13 maps

$€ 85 \$ 106 \quad £ 59 ¥ 10,900$

Renewables Information 2004

ISBN 9264107541

204p

$€ 80 \$ 100 \quad £ 55 \quad ¥ 10,200$

Nuclear Production of Hydrogen: Second Information Exchange

Meeting

ISBN 9264107703

$316 \mathrm{p}$

$€ 65 \$ 81 \quad £ 45 \quad ¥ 8,300$

This report presents the state of the art in the nuclear production of hydrogen and the scientific and technical challenges associated with it.

\section{ENVIRONMENT}

The Benefits of Climate Change Policies

ISBN 9264108319 
$400 p, 20$ tables, 40 graphics

$€ 75 \$ 94 \quad £ 52 \quad ¥ 9,600$

What is the nature of avoided impact benefits from policies that limit global warming and how do these vary by sector or region? How do adaptation and mitigation policies interact?

OECD Environmental Performance

Reviews: Canada

ISBN 9264107762

232p, 29 tables, 65 graphics

$€ 37 \$ 46 £ 24 \quad ¥ 4,500$

OECD Environmental Performance

Reviews: Sweden

ISBN 9264108580

150 p, 22 tables, 14 graphics

$€ 37 \$ 46 \quad £ 24 \quad ¥ 4,500$

See review.

FINANCIAL AND

ENTERPRISE AFFAIRS

International Investment

Perspectives 2004

ISBN 926401649X

190p, 17 tables, 13 graphics

$€ 45 \$ 56 \quad £ 31 \quad$ Y5,700

Analysis of trends in foreign direct investment (FDI) flows into $\mathrm{OECD}$ countries, as well as FDI policies in Russia and ASEAN countries, and a look at regional and bilateral investment agreements.

Implementing the OECD Antibribery Convention

ISBN 9264101136

$389 \mathrm{p}$

$€ 375 \$ 431 \quad\{252 \quad ¥ 47,900$

Financial Market Trends, No. 87 OECD Code 272004021P1

150p, 12 tables, 15 graphics

Sold as subscription only.

\section{GOVERNANCE}

Mexico: Progress in Implementing

Regulatory Reform

ISBN 926401750X

233p, 21 graphics

$€ 40 \quad \$ 46 \quad £ 27 \quad ¥ 5,100 \quad$ MXN460

Japan: Progress in Implementing

Regulatory Reform

ISBN 9264017151

$112 \mathrm{p}$

\section{$24 \$ 29 \quad £ 17 \quad ¥ 3,000$}

This publication assesses the progress made since the first review in 1999 , covers the core issues of capacity for

\section{Latest OECD Policy Briefs}

Free online at www.oecd.org

Economic briefs on Surveys of Germany, Portugal, the Euro area, Russian Federation, Poland, Korea, the Netherlands

Employment Protection: Costs and Benefits of Job Security

Working Hours: Clocking In and Clocking Out

$\square$ Public Sector Modernisation: Modernising Public Employment

The OECD Principles of Corporate Governance

Access Pricing in Telecommunications

The Significance of Knowledge Management in the Public Sector

Agricultural Support: How is it Measured and What Does it Mean?

$\square$ Competition Law and Policy in Mexico

$\square$ Keeping Children Safe in Traffic

Mobilizing Public Opinion Against Global Poverty

regulatory quality, competition and market openness, and updates information about competition policy.

Germany: Consolidating Economic and Social Renewal

ISBN 9264107843

198 p, 12 tables, 16 graphics

$€ 40 \quad \$ 46 \quad £ 27 \quad ¥ 5,100$

\section{HEALTH}

Private Health Insurance in OECD

Countries

ISBN 9264015639

230 p, 35 tables, 25 graphics

$€ 50 \$ 63 \quad £ 35 \quad$ y6,400

First-ever comparative analysis of the role and performance of private health insurance (PHI) in OECD countries.

What is the impact of PHI on health systems? How does it affect coverage of and access to healthcare services?

Towards High-Performing Health Systems: Policy Studies ISBN 9264015590
332 p, 92 tables, 77 graphics €60 \$75 £42 $¥ 7,700$

\section{OECD Health Data 2004}

ISBN 9264106480

For-profit: $€ 325 \$ 406 \quad £ 225 \quad ¥ 41,800$

Not-for-profit: $€ 225 \$ 281 £ 156 ¥ 28,900$ CD-ROM

\section{STATISTICS}

Insurance Statistics Yearbook 1994 -

2001

ISBN 9264104615

$328 \mathrm{p}$

$€ 110 \$ 127 \quad € 74 ¥ 14,000$

Also available on CD-ROM and online.

Journal of Business Cycle

Measurement and Analysis:

Volume 1, No. 2

OECD Code 332004021P1

$126 p$

Sold as subscription only.

Includes: Consumer Sentiment and Economic Activity; Detecting Cyclical Turning Points; Markov Switching Models for GDP Growth in a Small Open Economy: The New Zealand Experience.

Central Government Debt:

Statistical Yearbook 1993-2002

ISBN 9264015728

430p, 150 tables

$€ 80 \quad \$ 100 \quad € 55 \quad ¥ 10,300$

Also available online.

\section{SUSTAINABLE}

\section{DEVELOPMENT}

Biomass and Agriculture:

Sustainability, Markets and Policies

ISBN 9264105549

$568 \mathrm{p}$

$€ 75 \quad \$ 86 \quad £ 53 \quad \ngtr 10,200$

What is the contribution of agricultural biomass to sustainable development? What issues should be addressed by policies? What are governments actually doing and how effective are they?

\section{Measuring Sustainable}

Development: Integrated Economic, Environmental and Social

Frameworks

ISBN 9264020128

$428 \mathrm{p}$

$€ 90 \quad \$ 104 \quad £ 63 \quad ¥ 12,300$

口

\section{TAXATION}

Revenue Statistics 1965-2003

ISBN 9264017852

300 p, 200 tables, 15 graphics

$€ 90 \$ 113 \quad$ £62 ¥11,500

Taxing Wages: 2002-2003

ISBN $926401523 \mathrm{X}$

420p, 146 tables, 10 graphics

$95 \$ 119 £ 666 \quad ¥ 12,200$

TRADE

A New World Map in Textiles and Clothing: Adjusting to Change ISBN 9264018557

210p, 77 tables, 14 graphics

$€ 31 \quad \$ 39 \quad 21 \quad ¥ 3,900$

See review

Trade and Migration: Building Bridges for Global Labour Mobility

Co-edited with the World Bank and International Organisation for Migration

ISBN 9264016384

$162 \mathrm{p}$

$€ 40 \$ 50 \quad\{28 \quad ¥ 5,100$

Does the temporary movement of natural persons to supply services known as mode 4 - contribute to "brain drain" in developing countries? And what are the links between mode 4 and the sensitive issue of how countries regulate the entry of foreigners into their territory?

Export Credit Financing Systems in OECD Member and Non-

Member Countries

ISBN 9264016538

- $378 \mathrm{p}$

$€ 60 \quad \$ 75 \quad £ 42 \quad ¥ 7,700$

\section{TRANSPORT}

European Integration

of Rail Freight Transport

ISBN 9282113191

$118 \mathrm{p}$

$€ 40 \quad \$ 50 \quad\{28 \quad ¥ 5,100$

Will the current railway operators keep pace with change or are they threatened with extinction? Are new firms going to be commercially viable in areas in which traditional operators have always failed? 


\section{Giving clothing new wings}

A New World Map in Textiles and Clothing: Adjusting to Change

In 2002, the textiles and clothing industry accounted for US\$350 billion or $5.6 \%$ of total merchandise exports. The industry employs tens of millions of people, primarily in developing countries. But dramatic changes are afoot, with new regulations set to come into force in January 2005.

Textiles is one of the hardest-fought issues in the World Trade Organization. The elimination of quantitative import restrictions under the WTO Agreement on Textiles and Clothing will put an end to a complex trade regime built up over decades, and will have huge implications for those involved in the entire supply chain. Countries will no longer be able to protect their own industries by means of restrictive quotas on imports of textile and clothing products. What will this mean for cotton growers in Burkina Faso or Turkey, fashion retailers in France or the United States, and shirt factories in Bangladesh, the Dominican Republic or China? Who stands to lose and who will gain? Where will jobs be at risk and new markets found? And how can governments help their own textile and clothing industries adjust to new market realities?
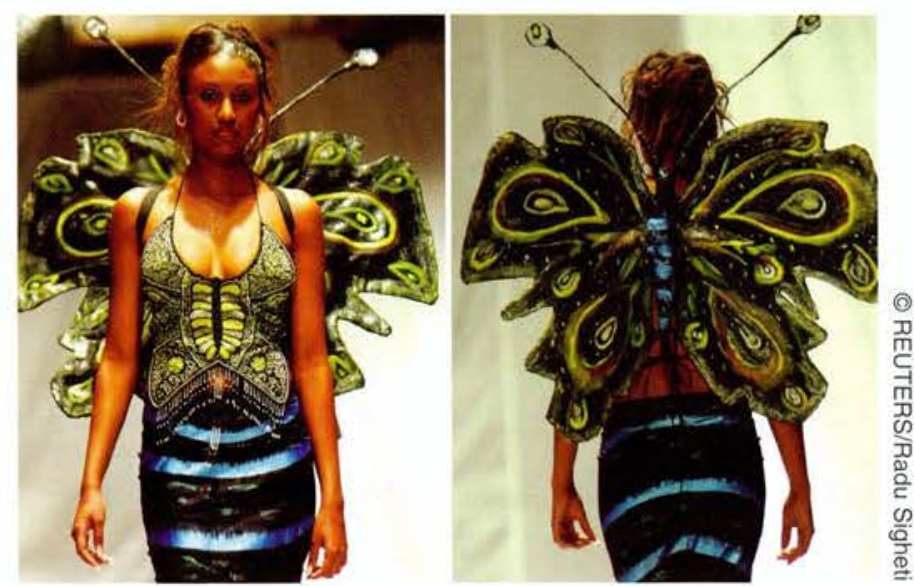

A New World Map in Textiles and Clothing argues that while large players like China stand to gain from the new situation, winners over time will be those - whether large or small - who master the logistics of the marketplace. They will manage costs, of course, but as crucially, will fill quality orders to short deadlines. The report also suggests a policy framework to help deal effectively with such changes, as well as to capitalise on the trade opportunities that are being created through improved market access.

ISBN 9264-018557. See the New Publications pages or www.oecd.org/bookshop for ordering details.

\section{ORDER FORM}

\section{Subscribe to the OECD OBSERVER}

\begin{tabular}{|c|c|c|}
\hline \multirow{3}{*}{$\begin{array}{l}\text { Yes, please enter my subscription for } \\
\text { six issues plus my free OECD in Figures } \\
\text { annual supplement, worth } € 15 \text {. }\end{array}$} & $\begin{array}{l}\square € 50 \\
\square U S \$ 50\end{array}$ & $\begin{array}{l}\text { Subscription will commence with the next available } \\
\text { issue. Subscribers will be provided with the English } \\
\text { language edition unless otherwise indicated. }\end{array}$ \\
\hline & $\square £ 31$ & English language edition (0100001P) ISSN 0029-7054 \\
\hline & 口 $¥ 5,900$ & French language edition (0100002P) ISSN 0304-3398 \\
\hline
\end{tabular}

You can order your BOOKS either online at wwwoecd.org/bookshop/ or by mailing your choices from the New publications titles in this section to one of the addresses below. Where do we deliver?

Name.......

Organisation ............................................................ Position held

Address

Country

Telephone.

Postcode

City

Fax

Payment details

Cheque/money order enclosed (payable to OECD)

$\square$ Please charge my VISAMMasterCard/American Express

TOTAL amount due

Card Expiry Date.

Card number

\section{Cor customers in Latin America}

\section{Where to send your mail or fax order}

$$
\begin{aligned}
& \text { For customers in Austria, } \\
& \text { Germany and Switzerland } \\
& \text { UNO Verlag } \\
& \text { Am Hofgarten 10 } \\
& 53113 \text { BONN, GERMANY } \\
& \text { Tel: (49-228) } 949020 \\
& \text { Fax: (49-228) } 9490222 \\
& \text { E-mail: oecd@uno-verlag.de } \\
& \text { Internet: } \\
& \text { www.oecd.org/deutschland }
\end{aligned}
$$

For customers in Asia
OECD TOKYO Centre
3rd Floor, Nippon Press Ctr. Bldg
2-2-1 Uchisaiwaicho, Chiyoda-ku
TOKYO 100-0011, JAPAN
Tel: (81-3) 55320021
Fax: (81-3) 55320035
E-mail: center@oecdtokyo.org
Internet: wwwoecdtokyo.org

For customers in Latin America OECD MEXICO Centre Av. Presidente Mazaryk 526 Colonia: Polanco C. P. 11560 MEXICO D.F, MEXICO Tel: (52-55) 52813810 Fax: (52-55) 52800480 E-mail: mexico.contact@oecd.org Internet: rtn.net.mx/ocde/
For customers in the United States OECD Distribution Center do Extenza-Turpin 56 Industrial Park Drive Pembroke, MA 02359, USA Toll free: (1-800) 4566323 Tel.: (1-781) 8267572

Fax: (1-781) 8299052 Email: OECDNA@extenza-turpin.com Internet: www.oecdwash.org
For customers in the rest of the world OECD do Turpin Distribution Services Lid.

Stratton Business Park,

Pegasus Drive, Biggleswade, Bedfordshire, SG18 8QB, UK Fax: (44)1767 601640 E-mail: books@extenza-turpin.com E-mail:

subscriptions@extenza-turpin.com 


\section{DATABANK}

OECD in graphs

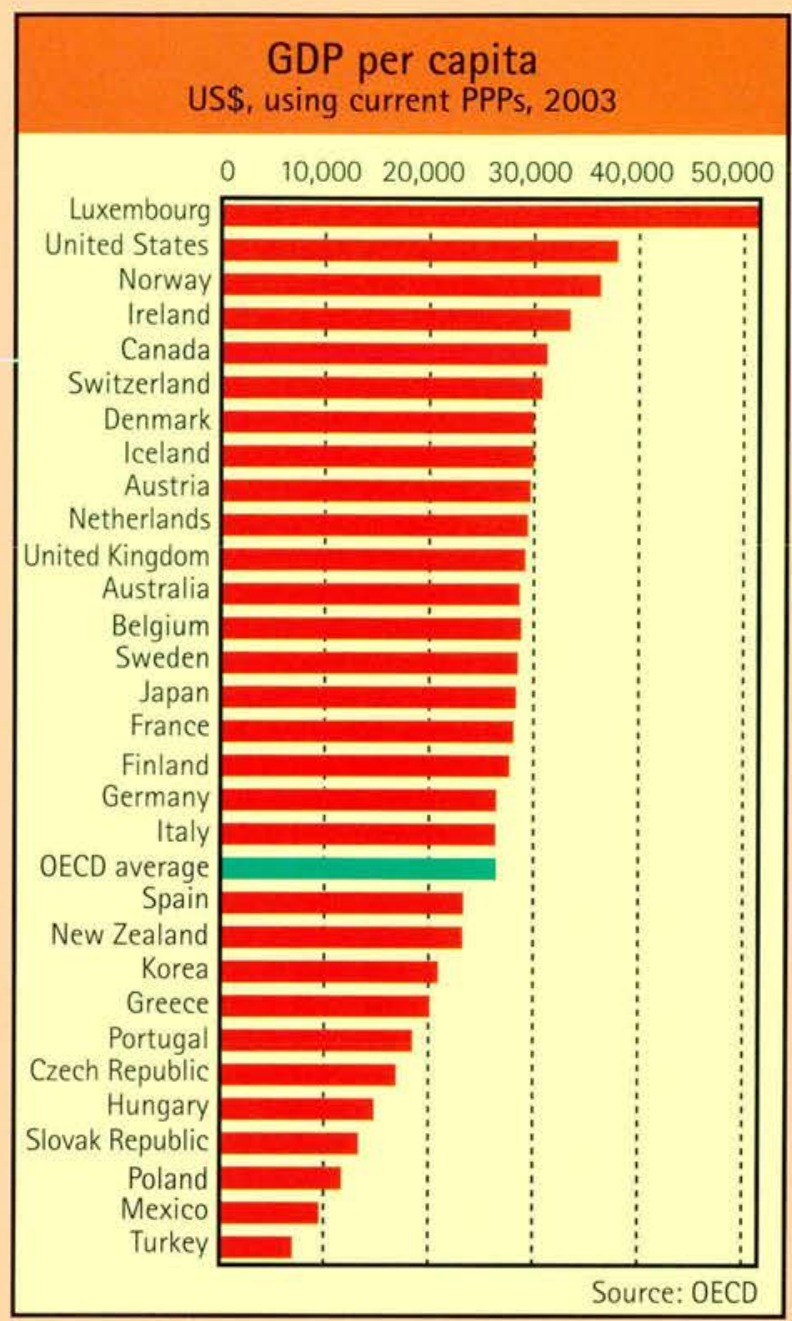

\section{At the top}

L

uxembourg had the highest GDP per head in 2003 , at over $\$ 50,000$, above the US, Norway and Ireland, according to the recently published annual pocket data book, OECD in Figures 2004. The US leads the G7, followed by Canada. Third is the UK, which at $\$ 29,000$ still lies beneath the G7 average, but well ahead of Germany, where GDP per capita was just $\$ 26,300$. GDP per head exceeded $\$ 30,000$ in six OECD countries, and in a further 13 countries it surpassed the OECD average of $\$ 26,000$ per head. GDP per head was around $\$ 10,000$ or below in just two countries: Mexico and Turkey. The usefulness of PPPs when looking at GDP per head is clear in the case of Japan; in current dollars, its GDP per head lies in the top ten in the $\mathrm{OECD}$ area, but when purchasing power differences with other countries are taken into account, it slides back to 15th. The online version of OECD in Figures, with 35 tables and 14 graphs covering a range of economic, social, environmental and scientific issues, is available at www.oecd.org/infigures.

\section{Sum of knowledge}

$\mathrm{H}$ ow much do our knowledge-based societies actually invest in knowledge? One way to find out, according to OECD Science, Technology and Industry Scoreboard published in May, is to work out the sum of three spending areas: $\mathrm{R} \& D$, higher education (public and private) and software. The figures are reworked where possible to avoid overlap between, say, education and R\&D. Nor does the available data include areas like spending on business innovation, design, training, organisation and the like. With these caveats in mind, the latest comparable data for the OECD comes from 2000, when average investment in knowledge came to $4.8 \%$ of GDP. Sweden spent the most on knowledge, with $7.2 \%$ of GDP, followed by the US $(6.8 \%)$ and Finland $(6.2 \%)$. Overall, the ratio is 2.8 percentage points higher in the US than in the EU. Investment in knowledge was lowest (below 2.5\% of GDP) in southern and central Europe, and Mexico.

Most OECD countries have increased spending in their knowledge base, the Scoreboard reports. In the 1990s, Denmark, Ireland, Finland and Sweden increased it by more than $7.5 \%$ annually, far above their increase in gross fixed capital formation, though this item grew more rapidly than knowledge investment in Australia, Canada and the US. For most countries, increases in software expenditure were the major source of increased investment in knowledge. OECD Science, Technology and Industry Scoreboard 2003, is available at www.oecd.org/bookshop. =

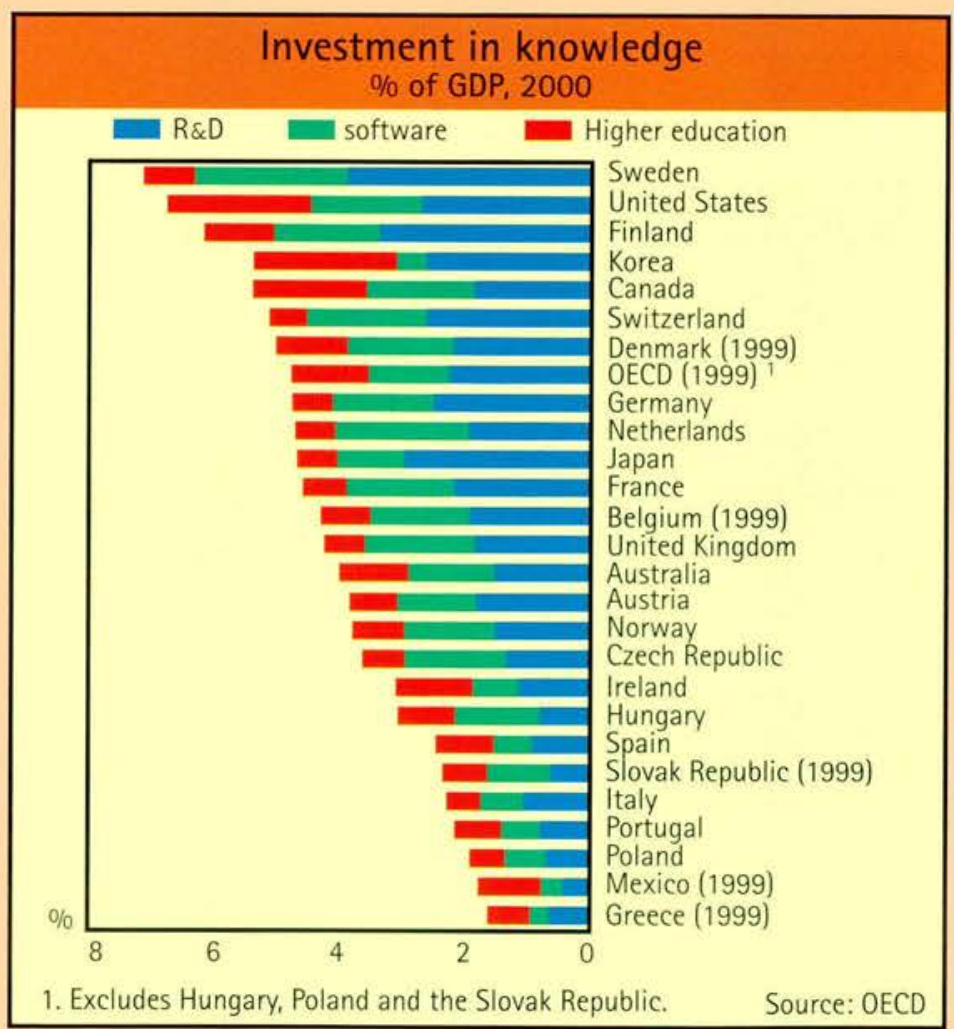




\begin{tabular}{|c|c|c|c|c|c|c|c|c|}
\hline & & & $\%$ chan & from: & & & & \\
\hline & & & $\begin{array}{l}\text { previous } \\
\text { period }\end{array}$ & $\begin{array}{l}\text { previous } \\
\text { year }\end{array}$ & & & $\begin{array}{l}\text { current } \\
\text { period }\end{array}$ & $\begin{array}{l}\text { same period } \\
\text { last year }\end{array}$ \\
\hline Australia & Gross domestic product & Q2 04 & 0.60 & 4.10 & Current balance & Q2 04 & -8.55 & -7.77 \\
\hline & Leading indicator & Jun. 04 & 0.50 & 2.60 & Unemployment rate & Jul. 04 & 5.70 & 6.20 \\
\hline & Consumer price index & Q2 04 & 0.50 & 2.50 & Interest rate & Aug. 04 & 5.44 & 4.82 \\
\hline Austria & Gross domestic product & Q1 04 & 0.20 & 0.50 & Current balance & Q1 04 & -0.32 & -0.49 \\
\hline & Leading indicator & Jul. 04 & 0.60 & 8.90 & Unemployment rate & Jul. 04 & 4.20 & 4.20 \\
\hline & Consumer price index & Jul. 04 & -0.10 & 2.30 & Interest rate & & * & * \\
\hline Belgium & Gross domestic product & Q2 04 & 0.80 & 2.80 & Current balance & Q1 04 & 3.14 & 2.78 \\
\hline & Leading indicator & Jul. 04 & 0.40 & 7.60 & Unemployment rate & Jul. 04 & 8.60 & 8.20 \\
\hline & Consumer price index & Aug. 04 & 0.10 & 2.30 & Interest rate & & * & * \\
\hline Canada & Gross domestic product & Q2 04 & 1.10 & 3.00 & Current balance & Q2 04 & 7.66 & 3.79 \\
\hline & Leading indicator & Jul. 04 & 0.10 & 4.90 & Unemployment rate & Jul. 04 & 7.20 & 7.70 \\
\hline & Consumer price index & Jul. 04 & -0.10 & 2.30 & Interest rate & Aug. 04 & 2.14 & 2.86 \\
\hline Czech Republic & Gross domestic product & Q4 03 & 0.70 & 3.20 & Current balance & Q2 04 & -1.72 & -1.51 \\
\hline & Leading indicator & & .. & .. & Unemployment rate & Jul. 04 & 8.80 & 7.90 \\
\hline & Consumer price index & Aug. 04 & 0.00 & 3.40 & Interest rate & Aug. 04 & 2.57 & 2.06 \\
\hline Denmark & Gross domestic product & Q2 04 & 0.20 & 2.50 & Current balance & Q2 04 & 2.05 & 1.56 \\
\hline & Leading indicator & Jul. 04 & 1.30 & 9.10 & Unemployment rate & Jul. 04 & 5.90 & 5.70 \\
\hline & Consumer price index & Jul. 04 & -0.40 & 1.30 & Interest rate & Aug. 04 & 2.15 & 2.14 \\
\hline Finland & Gross domestic product & Q1 04 & 0.80 & 2.50 & Current balance & Jun. 04 & 0.95 & 0.80 \\
\hline & Leading indicator & Jul. 04 & 0.20 & 3.50 & Unemployment rate & Jul. 04 & 9.00 & 9.00 \\
\hline & Consumer price index & Jul. 04 & -0.10 & 0.30 & Interest rate & & * & * \\
\hline France & Gross domestic product & Q2 04 & 0.80 & 3.00 & Current balance & Jun. 04 & -0.62 & 1.15 \\
\hline & Leading indicator & Jul. 04 & 0.40 & 7.10 & Unemployment rate & Jul. 04 & 9.50 & 9.50 \\
\hline & Consumer price index & Jul. 04 & -0.20 & 2.30 & Interest rate & & * & * \\
\hline Germany & Gross domestic product & Q2 04 & 0.50 & 1.50 & Current balance & Q2 04 & 30.73 & 8.59 \\
\hline & Leading indicator & Jul. 04 & 0.00 & 6.50 & Unemployment rate & Jul. 04 & 9.90 & 9.70 \\
\hline & Consumer price index & Aug. 04 & 0.20 & 2.00 & Interest rate & & * & * \\
\hline Greece & Gross domestic product & Q2 04 & -0.60 & 3.90 & Current balance & Jun. 04 & -0.87 & -0.94 \\
\hline & Leading indicator & Jul. 04 & -0.40 & 1.30 & Unemployment rate & Dec. 03 & 9.30 & 9.50 \\
\hline & Consumer price index & Jul. 04 & -1.80 & 2.90 & Interest rate & & * & * \\
\hline Hungary & Gross domestic product & Q1 04 & -7.80 & 4.20 & Current balance & Apr. 04 & -0.99 & -0.60 \\
\hline & Leading indicator & & .. & .. & Unemployment rate & Jul. 04 & 5.90 & 5.70 \\
\hline & Consumer price index & Jul. 04 & 0.00 & 7.20 & Interest rate & Jul. 04 & 11.46 & 9.44 \\
\hline Iceland & Gross domestic product & Q1 04 & -5.70 & 4.90 & Current balance & Q2 04 & -0.16 & -0.18 \\
\hline & Leading indicator & &.. & .. & Unemployment rate & Jul. 04 & 3.60 & 3.50 \\
\hline & Consumer price index & Aug. 04 & 0.00 & 3.70 & Interest rate & Jul. 04 & 6.05 & 5.10 \\
\hline Ireland & Gross domestic product & Q1 04 & -1.70 & 6.10 & Current balance & Q1 04 & -0.81 & -0.90 \\
\hline & Leading indicator & Jul. 04 & 0.60 & 14.40 & Unemployment rate & Jul. 04 & 4.50 & 4.70 \\
\hline & Consumer price index & Jul. 04 & -0.30 & 2.70 & Interest rate & & * & * \\
\hline tialy & Gross domestic product & Q2 04 & 0.30 & 1.10 & Current balance & Mar. 04 & 0.83 & -1.42 \\
\hline & Leading indicator & Jul. 04 & -0.20 & 0.00 & Unemployment rate & Jan. 04 & 8.50 & 8.90 \\
\hline & Consumer price index & Aug. 04 & 0.20 & 2.30 & Interest rate & & * & * \\
\hline Japan & Gross domestic product & Q2 04 & 0.40 & 4.50 & Current balance & Jun. 04 & 11.98 & 9.50 \\
\hline & Leading indicator & Jul. 04 & -0.10 & 1.20 & Unemployment rate & Jul. 04 & 4.90 & 5.30 \\
\hline & Consumer price index & Jul. 04 & -0.30 & -0.10 & Interest rate & Jul. 04 & 0.03 & 0.04 \\
\hline Korea & Gross domestic product & Q2 04 & 0.60 & 5.80 & Current balance & Jul. 04 & 4.77 & 1.17 \\
\hline & Leading indicator & & .. &.. & Unemployment rate & Jul. 04 & 3.60 & 3.50 \\
\hline & Consumer price index & Aug. 04 & 0.90 & 4.80 & Interest rate & Jul. 04 & 3.90 & 4.20 \\
\hline
\end{tabular}




\begin{tabular}{|c|c|c|c|c|c|c|c|c|}
\hline & & & $\%$ cha & from: & & & & vel: \\
\hline & & & $\begin{array}{l}\text { previous } \\
\text { period }\end{array}$ & $\begin{array}{c}\text { previous } \\
\text { year }\end{array}$ & & & $\begin{array}{l}\text { current } \\
\text { period }\end{array}$ & $\begin{array}{l}\text { same period } \\
\text { last year }\end{array}$ \\
\hline Luxembourg & Gross domestic product & 2003 &.. & 2.10 & Current balance & Q1 04 & 0.73 & 0.15 \\
\hline & Leading indicator & Jul. 04 & 0.30 & 14.50 & Unemployment rate & Jul. 04 & 4.30 & 3.80 \\
\hline & Consumer price index & Aug. 04 & 1.20 & 3.00 & Interest rate & & * & * \\
\hline Mexico & Gross domestic product & Q2 04 & 1.20 & 3.90 & Current balance & Q1 04 & -2.28 & -2.33 \\
\hline & Leading indicator & Jul. 04 & 1.20 & 4.60 & Unemployment rate & Jun. 04 & 3.70 & 3.60 \\
\hline & Consumer price index & Jul. 04 & 0.30 & 4.50 & Interest rate & Aug. 04 & 7.50 & 5.11 \\
\hline Netherlands & Gross domestic product & Q2 04 & -0.20 & 1.10 & Current balance & Q2 04 & 7.26 & 4.43 \\
\hline & Leading indicator & Jul. 04 & 0.40 & 6.30 & Unemployment rate & Jun. 04 & 4.80 & 3.80 \\
\hline & Consumer price index & Aug. 04 & 0.30 & 1.10 & Interest rate & & * & * \\
\hline $\mathrm{Nev}$ & Gross domestic product & Q1 04 & 2.00 & 4.40 & Current balance & Q1 04 & -0.81 & -0.61 \\
\hline & Leading indicator & &.. &.. & Unemployment rate & Q2 04 & 4.00 & 4.70 \\
\hline & Consumer price index & Q2 04 & 0.80 & 2.40 & Interest rate & Aug. 04 & 6.43 & 5.11 \\
\hline Norway & Gross domestic product & Q1 04 & 1.00 & 2.90 & Current balance & Q2 04 & 7.85 & 6.48 \\
\hline & Leading indicator & Jul. 04 & 1.00 & 5.90 & Unemployment rate & Jun. 04 & 4.50 & 4.70 \\
\hline & Consumer price index & Jul. 04 & -0.10 & 1.50 & Interest rate & Aug. 04 & 2.02 & 3.14 \\
\hline Poland & Gross domestic product & Q1 04 & -10.70 & 7.60 & Current balance & Jun. 04 & 0.05 & -0.16 \\
\hline & Leading indicator & & .. & .. & Unemployment rate & Jul. 04 & 18.80 & 19.20 \\
\hline & Consumer price index & Jul. 04 & -0.10 & 4.50 & Interest rate & Jul. 04 & 5.85 & 5.02 \\
\hline Portug & Gross domestic product & Q1 04 & 0.60 & 0.10 & Current balance & Jun. 04 & -0.49 & -0.82 \\
\hline & Leading indicator & Jul. 04 & 0.60 & 2.20 & Unemployment rate & Jul. 04 & 6.40 & 6.20 \\
\hline & Consumer price index & Jul. 04 & -0.20 & 2.80 & Interest rate & & * & * \\
\hline Slovak Republic & Gross domestic product & Q1 04 & -4.00 & 5.50 & Current balance & Q1 04 & 0.04 & -0.22 \\
\hline & Leading indicator & & .. &. & Unemployment rate & Jul 04 & 15.90 & 17.00 \\
\hline & Consumer price index & Aug. 04 & -0.20 & 7.20 & Interest rate & Jul. 04 & 8.26 & 7.15 \\
\hline Spain & Gross domestic product & Q2 04 & 0.50 & 2.60 & Current balance & May. 04 & -4.20 & -2.32 \\
\hline 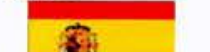 & Leading indicator & Jul. 04 & -0.80 & 0.70 & Unemployment rate & Jul. 04 & 11.00 & 11.30 \\
\hline & Consumer price index & Jul. 04 & -0.80 & 3.40 & Interest rate & & * & * \\
\hline Sweden & Gross domestic product & Q2 04 & 0.90 & 3.30 & Current balance & Q2 04 & 6.44 & 4.25 \\
\hline & Leading indicator & Jun. 04 & 0.10 & 8.00 & Unemployment rate & Jul. 04 & 6.40 & 5.60 \\
\hline & Consumer price index & Jul. 04 & -0.10 & 0.60 & Interest rate & Aug. 04 & 1.99 & 2.71 \\
\hline Switzerland & Gross domestic product & Q1 04 & 0.40 & 1.60 & Current balance & Q1 04 & 12.22 & 7.35 \\
\hline & Leading indicator & Jul. 04 & -0.60 & 4.20 & Unemployment rate & Q2 04 & 4.30 & 4.30 \\
\hline & Consumer price index & Aug. 04 & 0.40 & 1.00 & Interest rate & Jul. 04 & 0.53 & 0.29 \\
\hline Turkey & Gross domestic product & Q1 04 & -11.90 & 10.10 & Current balance & Q2 04 & -3.87 & -2.08 \\
\hline & Leading indicator & Jul. 04 & 0.90 & 4.60 & Unemployment rate & Q1 04 & 12.40 & 12.30 \\
\hline & Consumer price index & Aug. 04 & 0.60 & 10.00 & Interest rate & Aug. 04 & 22.55 & 30.66 \\
\hline United Kingdom & Gross domestic product & Q2 04 & 0.90 & 3.70 & Current balance & Q1 04 & -9.79 & -4.01 \\
\hline & Leading indicator & Jul. 04 & -0.80 & 1.40 & Unemployment rate & May. 04 & 4.70 & 4.90 \\
\hline & Consumer price index & Jul. 04 & 0.00 & 3.00 & Interest rate & Jul. 04 & 4.79 & 3.42 \\
\hline United States & Gross domestic product & Q2 04 & 0.70 & 4.70 & Current balance & Q1 04 & -144.88 & -138.21 \\
\hline & Leading indicator & Jul. 04 & 0.10 & 7.20 & Unemployment rate & Aug. 04 & 5.40 & 6.10 \\
\hline & Consumer price index & Jul. 04 & -0.20 & 3.00 & Interest rate & Aug. 04 & 1.68 & 1.08 \\
\hline Euro area & Gross domestic product & Q2 04 & 0.50 & 1.90 & Current balance & Jun. 04 & -0.61 & -1.28 \\
\hline & Leading indicator & Jul. 04 & 0.00 & 4.80 & Unemployment rate & Jul. 04 & 9.00 & 8.90 \\
\hline & Consumer price index & Jul. 04 & -0.20 & 2.40 & Interest rate & Aug, 04 & 2.11 & 2.14 \\
\hline
\end{tabular}

Definitions and notes

Gross Domestic Product: Volume series; seasonally adjusted except for Hungary, Iceland, Ireland, Poland, Slovak Republic and Turkey; Leading Indicators: A composite indicator based on other indicators of economic activity (qualitative opinions on production or employment, housing permits, financial or monetary series, etc), which signals cyclical movements in industrial production from six to nine months in advance; Consumer Price Index: Measures changes in average retail prices of a fixed basket of goods and services; Current Balance: USS billion; seasonally adjusted except for Greece, Ireland and the Netherlands; Unemployment Rate: \% of civilian labour force - standardised unemployment rate; national definitions for Iceland, Korea, Mexico and Turkey; seasonally adjusted, except for Turkey; Interest Rate: Three months. * refer to Euro zone. ..=not available.

Sourc: Main Economic Indicators, September 2004 


\section{Public or private?}

A Ithough health systems are funded by public and private finance in all OECD countries, the public sector remains the main source everywhere, except in the US and Mexico, accounting for an average of $72.5 \%$ of health spending in 26 OECD countries. In some, including the Czech Republic, Denmark and the UK, the public share accounted for more than $80 \%$. In the US there was an increase in its public share of health spending in the 1990s, reflecting policies to meet more of the needs of the elderly and poor. Private insurance plays a significant role in the US - 36\% of total health expenditure in 2002 - and it accounts for relatively large shares of funding in Canada, France, Germany and the Netherlands. Out-of-pocket payments from households form more than $30 \%$ of total health expenditure in Switzerland, Korea and Mexico. The share of public funding has increased considerably in Korea and Portugal, but has fallen in Hungary and Poland. -

\section{Rising aid}

$\mathrm{R}$ eaching the Millennium Development Goals by the internationally agreed date of 2015 will require a major funding effort (see page 18). If commitments from the OECD countries that make up the Development Assistance Committee (DAC) are upheld, then official development assistance (ODA) should rise. The pledges made in Monterrey, Mexico, in 2002, for instance, are for aid flows to increase to $\$ 86$ billion by 2006 , the largest rise in the DAC's 43-year history. Italy, already the world's seventh largest donor, has reaffirmed its commitment to double its aid in a recent DAC review. According to simulations published in the latest DAC Journal, total aid from its 22 member countries could rise by $27 \%$ in real terms. The US, which is the world's largest donor by value, will increase its aid by $32 \%$, or $\$ 5.1$ billion in real terms, while the combined EU total will rise by $31 \%$, or $\$ 11.5$ billion. The simulations for 2006 show large percentage increases from Austria, Greece and Portugal, with the lowest increases coming from the Japanese (7\%), Danes and Swiss ( $5 \%$ each), and the Dutch ( $4 \%)$. But whereas the Danes and Dutch already figure among the five DAC countries to surpass the UN recommended target for aid of $0.7 \%$ of gross national income (GNI), the Swiss ratio will hold steady, at $0.38 \%$ of $\mathrm{GNI}$ and the Japanese ratio will grow from $0.20 \%$ to $0.22 \%$ of GNI. Meanwhile, the UK and Spain have announced their intention to reach the $0.7 \%$ target, so bringing to 11 the number of DAC member countries to have either met it or announced a date by which to meet it. If these and earlier commitments are maintained, they would lift total ODA to over $\$ 100$ billion by 2010 . The DAC's member countries account for over $90 \%$ of global bilateral ODA. Visit www.oecd.org/development.

\section{Public health expenditure \\ $\%$ of total expenditure, $2002^{*}$}

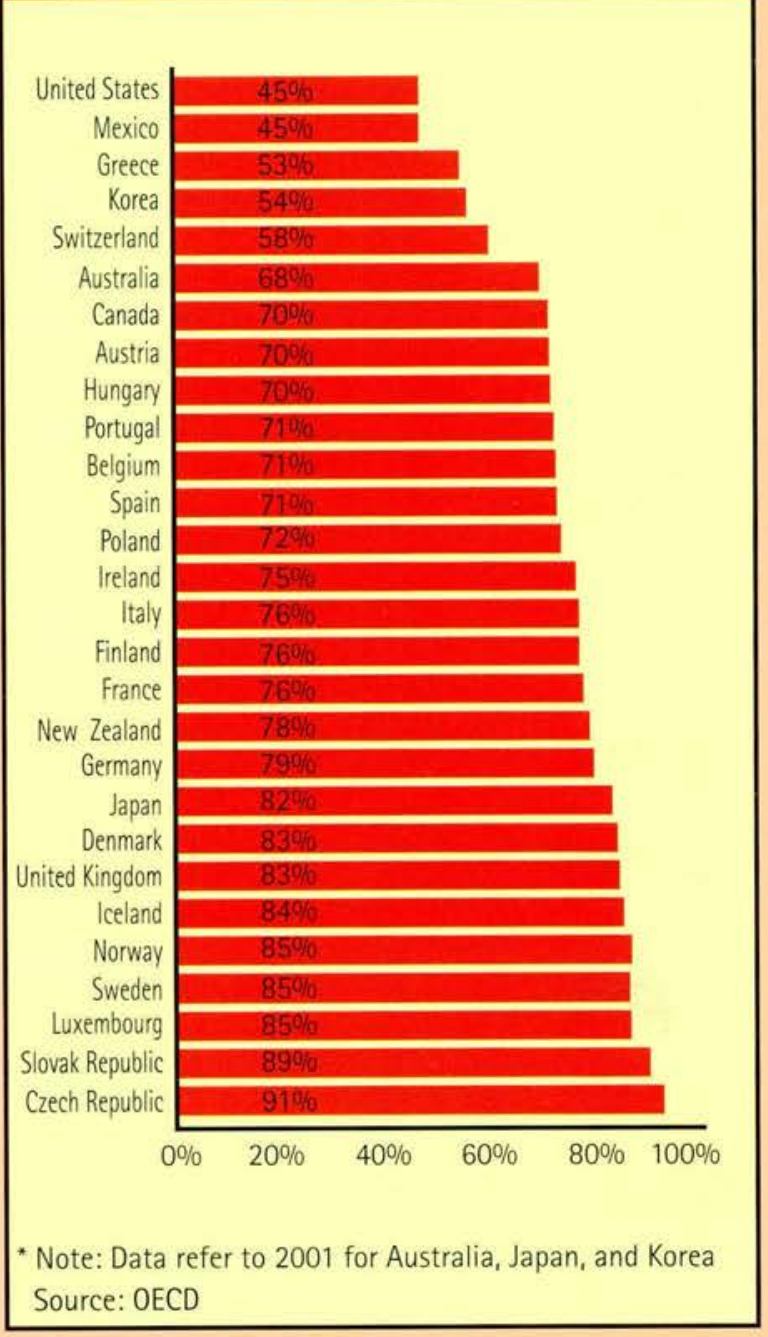

Source: $O E C D$

Rising aid

Simulation of aid prospects for 2006 compared with 2003, $\%$ real change, ODA

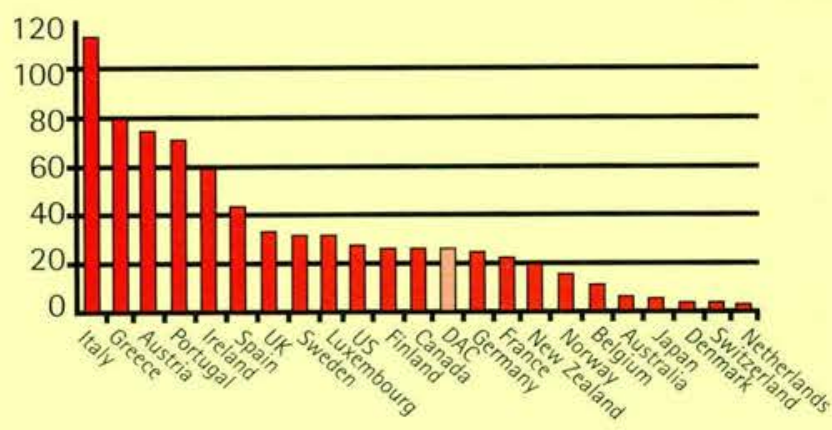

A detailed table is available on page 21 of the source.

Source: The DAC Journal, Vol. 5, n², 2004, available at www.oecd.org/bookshop 
